\title{
CCR5 antagonist reduces HIV-induced amyloidogenesis, tau pathology, neurodegeneration, and blood-brain barrier alterations in HIV-infected hu-PBL-NSG mice
}

Biju Bhargavan', Shawna M. Woollard ${ }^{1,2}$, Jo Ellyn McMillan ${ }^{1}$ and Georgette D. Kanmogne ${ }^{1 *}$ (i)

\begin{abstract}
Background: Neurocognitive impairment is present in 50\% of HIV-infected individuals and is often associated with Alzheimer's Disease (AD)-like brain pathologies, including increased amyloid-beta (A $\beta$ ) and Tau hyperphosphorylation. Here, we aimed to determine whether HIV-1 infection causes AD-like pathologies in an HIV/AIDS humanized mouse model, and whether the CCR5 antagonist maraviroc alters HIV-induced pathologies.

Methods: NOD/scid-IL-2R ${ }_{c}{ }^{\text {null }}$ mice engrafted with human blood leukocytes were infected with HIV-1, left untreated or treated with maraviroc (120 mg/kg twice/day). Human cells in animal's blood were quantified weekly by flow cytometry. Animals were sacrificed at week-3 post-infection; blood and tissues viral loads were quantified using p24 antigen ELISA, RNAscope, and qPCR. Human (HLA-DR+) cells, A $\beta-42$, phospho-Tau, neuronal markers (MAP 2, NeuN, neurofilament-L), gamma-secretase activating protein (GSAP), and blood-brain barrier (BBB) tight junction (TJ) proteins expression and transcription were quantified in brain tissues by immunohistochemistry, immunofluorescence, immunoblotting, and qPCR. Plasma A $\beta-42, A \beta-42$ cellular uptake, release and transendothelial transport were quantified by ELISA.
\end{abstract}

\footnotetext{
* Correspondence: gkanmogne@unmc.edu

'Department of Pharmacology and Experimental Neuroscience, College of Medicine, University of Nebraska Medical Center, 985800 Nebraska Medical Center, Omaha, NE 68198-5800, USA

Full list of author information is available at the end of the article
}

C C The Author(s). 2021 Open Access This article is licensed under a Creative Commons Attribution 4.0 International License, which permits use, sharing, adaptation, distribution and reproduction in any medium or format, as long as you give appropriate credit to the original author(s) and the source, provide a link to the Creative Commons licence, and indicate if changes were made. The images or other third party material in this article are included in the article's Creative Commons licence, unless indicated otherwise in a credit line to the material. If material is not included in the article's Creative Commons licence and your intended use is not permitted by statutory regulation or exceeds the permitted use, you will need to obtain permission directly from the copyright holder. To view a copy of this licence, visit http://creativecommons.org/licenses/by/4.0/. The Creative Commons Public Domain Dedication waiver (http://creativecommons.org/publicdomain/zero/1.0/) applies to the data made available in this article, unless otherwise stated in a credit line to the data. 
Results: HIV-1 significantly decreased human (h)CD4+ T-cells and hCD4/hCD8 ratios; decreased the expression of BBB TJ proteins claudin-5, ZO-1, ZO-2; and increased HLA-DR+ cells in brain tissues. Significantly, HIV-infected animals showed increased plasma and brain Aß-42 and phospho-Tau (threonine181, threonine231, serine396, serine199), associated with transcriptional upregulation of GSAP, an enzyme that catalyzes A $\beta$ formation, and loss of MAP 2, NeuN, and neurofilament-L. Maraviroc treatment significantly reduced blood and brain viral loads, prevented HIV-induced loss of neuronal markers and TJ proteins; decreased HLA-DR+ cells infiltration in brain tissues, significantly reduced HIVinduced increase in A $\mathrm{A}-42, \mathrm{GSAP}$, and phospho-Tau. Maraviroc also reduced $A \beta$ retention and increased $A \beta$ release in human macrophages; decreased the receptor for advanced glycation end products (RAGE) and increased low-density lipoprotein receptor-related protein-1 (LRP1) expression in human brain endothelial cells. Maraviroc induced A $\beta$ transendothelial transport, which was blocked by LRP1 antagonist but not RAGE antagonist.

Conclusions: Maraviroc significantly reduced HIV-induced amyloidogenesis, GSAP, phospho-Tau, neurodegeneration, BBB alterations, and leukocytes infiltration into the CNS. Maraviroc increased cellular A $\beta$ efflux and transendothelial A $\beta$ transport via LRP1 pathways. Thus, therapeutically targeting CCR5 could reduce viremia, preserve the BBB and neurons, increased brain A $\beta$ efflux, and reduce AD-like neuropathologies.

Keywords: HIV-1, NSG mice, Amyloid-beta, Tau phosphorylation, Neuronal damage, Blood-brain barrier injury, CCR5, Maraviroc, Monocytes-derived macrophages, Human brain microvascular endothelial cells, RAGE, LRP1

\section{Background}

The human immunodeficiency virus-1 (HIV-1) enters target cells by binding its envelope glycoprotein gp160 to the $\mathrm{CD} 4$ receptor and/or coreceptors such as the $\mathrm{C}-\mathrm{C}$ chemokine receptor type-5 (CCR5) and C-X-C chemokine receptor type-4 (CXCR4) [1]. CCR5- and CXCR4-tropic viral strains use CCR5 and CXCR4, respectively, as their coreceptor to enter and infect target cells; whereas some HIV strains are dual-tropic and can use CCR5 and/or CXCR4 [1]. CCR5 is expressed on several cell types, including brain endothelial cells [2], T-cells, dendritic cells, and leukocytes [3, 4]. In HIV-infected humans, CCR5-tropic viruses predominate during the early stages of infection, whereas CXCR4-tropic viruses usually emerge during the later stages $[3,4]$. The importance of CCR5 in HIV infection and acquired immunodeficiency syndrome (AIDS) pathology was demonstrated by studies showing that a 32base-pair deletion in the CCR5 gene resulted in resistance to HIV-1 infection or slower progression to AIDS [5, 6]. Given the importance of CCR5 in HIV-1 transmission, infection, and disease progression, this chemokine receptor has been a major therapeutic target for HIV/AIDS prevention and treatment. Maraviroc (MVC, Selzentry, ViiV Healthcare) is a small-molecule CCR5 antagonist with favorable safety, pharmacokinetic, and pharmacodynamic profiles $[7,8]$ that is FDA-approved for the treatment of CCR5-tropic HIV infection in both antiretroviral therapy (ART)-naïve and treatment-experienced patients $[9,10]$.

Following infection, HIV induces blood-brain barrier (BBB) injury, enters the central nervous system (CNS), and productively infects brain macrophages and glial cells [11-13]. This infection of CNS cells, production and release of virions and viral proteins into the brain, as well as subsequent increased inflammation and oxidative stress, results in neuronal injury and death [13-15]. These brain pathologies frequently result in behavioral, motor, and cognitive abnormalities referred to as HIV-associated neurocognitive disorders (HAND) $[13,15,16]$. Although the prevalence of HIV-associated dementia, the most severe form of HAND, has declined in the current ART era, milder forms of HAND [asymptomatic neurocognitive impairment and mild neurocognitive disorders] are still highly prevalent and occur in up to $50 \%$ of HIV-infected persons $[13,15,16]$.

The molecular mechanisms associated with the development of HAND have not been well elucidated. Autopsy studies of HIV-infected people, including those who had been on long-term ART, showed the presence of proteopathy and Alzheimer's Disease (AD)-like CNS pathologies, including increased deposits of amyloid-beta $(A \beta)$, formation of amyloid plaques in neuronal cells and perivascular areas, hyperphosphorylation of Tau proteins, and the presence of neurofibrillary tangles (NFTs)-like structures [1720]. The presence of $A \beta$ deposits and Tau hyperphosphorylation in brain tissues of HIV-infected persons is often associated with high viral loads [21] and neurocognitive impairments, including impairments in speed of information processing, attention, and working memory [21, 22]. For the current study, our objective was to determine whether AD-like pathologies occur in a humanized mouse model of HIV/AIDS [NOD/scid-IL-2R $\gamma_{c}{ }^{\text {null }}$ mice engrafted with human blood leukocytes (hu-PBL-NSG)] and to assess the effects of the CCR5 antagonist MVC on HIV-induced brain pathologies in vivo. We have reproduced AD-like pathologies in this animal model. We demonstrate increased phosphorylation of Tau [at threonine (Thr)181, Thr231, serine (Ser)396, and Ser199)], and increased production and accumulation of $A \beta$ in brain 
tissues and plasma of HIV-infected animals associated with transcriptional upregulation of gamma-secretase activating protein (GSAP), an endoprotease that catalyzes $\gamma$ secretase cleavage of amyloid precursor proteins (APP) and $A \beta$ formation [23-26]. Most significantly, we have demonstrated that in addition to preserving the immune system and decreasing systemic and brain viral loads, the CCR5 antagonist MVC reduced HIV-induced $\mathrm{BBB}$ alterations and infiltration of leukocytes into the brain of infected animals, and significantly reduced HIVinduced neuronal injury, CNS A $\beta$ formation, and Tau phosphorylation. Additional studies showed that MVC increased plasma $A \beta$ levels, reduced $A \beta$ retention and increased $A \beta$ release in primary human macrophages; decreased brain endothelial expression of the receptor for advanced glycation end products (RAGE), an influx receptor that binds and transports circulating plasma $A \beta$ into the CNS [27-30]; increased brain endothelial expression of the low-density lipoprotein receptor-related protein-1 (LRP1), an efflux-clearance receptor that binds and transports brain-derived $A \beta$ into the blood [31-33]; and increased transendothelial $A \beta$ transport via LRP1. These data suggest that therapeutically targeting CCR5 can reduce or abrogate HIV-induced AD-like neuropathologies.

\section{Methods}

\section{Hu-PBL-NSG mice model}

Four-week-old NOD/scid-IL-2R $\gamma_{c}{ }^{\text {null }}$ (NSG) mice were purchased from the Jackson Laboratory (Bar Harbor, ME), maintained in sterile microisolator cages under pathogen-free conditions in accordance with the University of Nebraska Medical Center (UNMC) and National Institutes of Health (NIH) ethical guidelines for the care of laboratory animals, and bred at the UNMC animal facility to expand the colony. This study was performed under a protocol approved by the UNMC Institutional Animal Care and Use Committee. Human peripheral blood lymphocytes (PBL) were obtained by countercurrent centrifugal elutriation of leukopheresis packs from HIV-1, 2, and hepatitis B seronegative donors, as previously described [34]. Mice (4 to 6 weeks old males) were engrafted by intra-peritoneal (i.p.) injection of human PBL $\left(30 \times 10^{6}\right.$ cells/mouse). One week after PBL injection, levels of human CD45+ cells in each animal's blood were quantified by fluorescence activated cell sorting (FACS) to confirm engraftment. Engrafted animals were randomly assigned into 4 groups (11 to 15 mice per group): non-treated and non-infected mice (PBS); noninfected animals treated with MVC (MVC); untreated and HIV-infected mice (HIV), HIV-infected mice treated with MVC (HIV + MVC). For infection, a single dose of $10^{4}$ tissue culture infectious doses-50 (100 $\left.\mu \mathrm{l}\right)$ of HIV$1_{\mathrm{ADA}}$ (a CCR5-tropic viral strain) was injected (i.p.) into animals. Controls were mock-infected by i.p. injection of phosphate-buffered saline (PBS, $100 \mu \mathrm{l})$. Animals' blood samples were collected and analyzed at week-1, week-2, and week-3 post infection (p.i.). Animals were sacrificed at week-3 p.i. and tissue samples harvested and analyzed (Fig. 1).

\section{Processing of brain tissues}

Immediately following animals' sacrifice, each brain lobe was cut (at the midbrain region) into two equal parts (coronal plane), for a total of 4 equal parts. One half lobe was embedded into paraffin (for immunohistochemistry), one half lobe was embedded into optimal cutting temperature (OCT) compound on dry ice and frozen at $-80^{\circ} \mathrm{C}$ (for immunofluorescence analyses). The remaining two half lobes were frozen at $-80^{\circ} \mathrm{C}$ and used for protein extraction and Western blot analysis, RNA extraction, and quantitative polymerase chain reaction (qPCR).

\section{Maraviroc (MVC) preparation}

MVC (Selzentry, ViiV Healthcare) was purchased from the UNMC pharmacy in $300 \mathrm{mg}$ tablets. To prepare stock concentrations of $75 \mathrm{mg} / \mathrm{ml}, 1$ tablet was crushed using a mortar and pestle and dissolved in $4 \mathrm{ml}$ of a 1:1 mixture of dimethyl sulfoxide (DMSO) and PBS. Stock solutions were stored at $-80{ }^{\circ} \mathrm{C}$ in $600 \mu \mathrm{l}$ aliquots and used within 2 days of preparation. For animal injections, $500 \mu \mathrm{l}$ stock solution was further diluted in $2 \mathrm{ml}$ PBS for a working concentration of $18.75 \mathrm{mg} / \mathrm{ml}$. This solution was passed through a $0.45 \mu \mathrm{m}$ syringe filter to remove undissolvable drug excipients. Each MVC-treated mouse was injected (i.p.) with MVC $(120 \mathrm{mg} / \mathrm{kg}, 200 \mu \mathrm{l})$ in a DMSO:PBS solution, twice/day, beginning at $12 \mathrm{~h}$ p.i. (Fig. 1). This dose and treatment schedule was based on recommended human MVC doses of 300-600 mg twice/ day and the consensus human-mouse interspecies allometric scaling factor of 12.6 [35, 36]. Untreated animals were injected (i.p.) with $200 \mu \mathrm{l}$ of a DMSO:PBS solution that had similar amounts of DMSO as the final MVC solution used for treatment.

\section{Antibodies}

Antibodies to human CD45 (CD45-PE-Cy7, catalog [cat] \#304016), CD8 (CD8-APC, cat \#344722), and CD3 (CD3-Pacific blue, cat \#300330) were purchased from Biolegend (San Diego, CA). Antibodies to human CD4 (CD4-FITC, cat \#555346) were from $\mathrm{BD}$ Biosciences (San Jose, $\mathrm{CA}$ ); human leukocyte antigen (HLA)-DR (cat \#NB100-77855SS), and Aß1-42 (cat \#NBP213075SS) from Novus Biologicals (Centennial, CO). Antibodies for microtubule-associated protein-2 (MAP 2, cat \#ab32454), neurofilament-L (NFL, cat \#ab223343), NeuN (cat \#ab177487), claudin-5 (cat \#ab15106), zonula occludens (ZO)-1 (cat \#617300), $\beta$-actin (cat \#ab8226), LRP1, (cat \#ab92544), RAGE (cat \#ab216329), phospho(p)-Tau (Ser396) (cat \#ab32057), pTau (Ser199) (cat \#ab4749), pTau (Thr231) (cat \#ab151559), and 


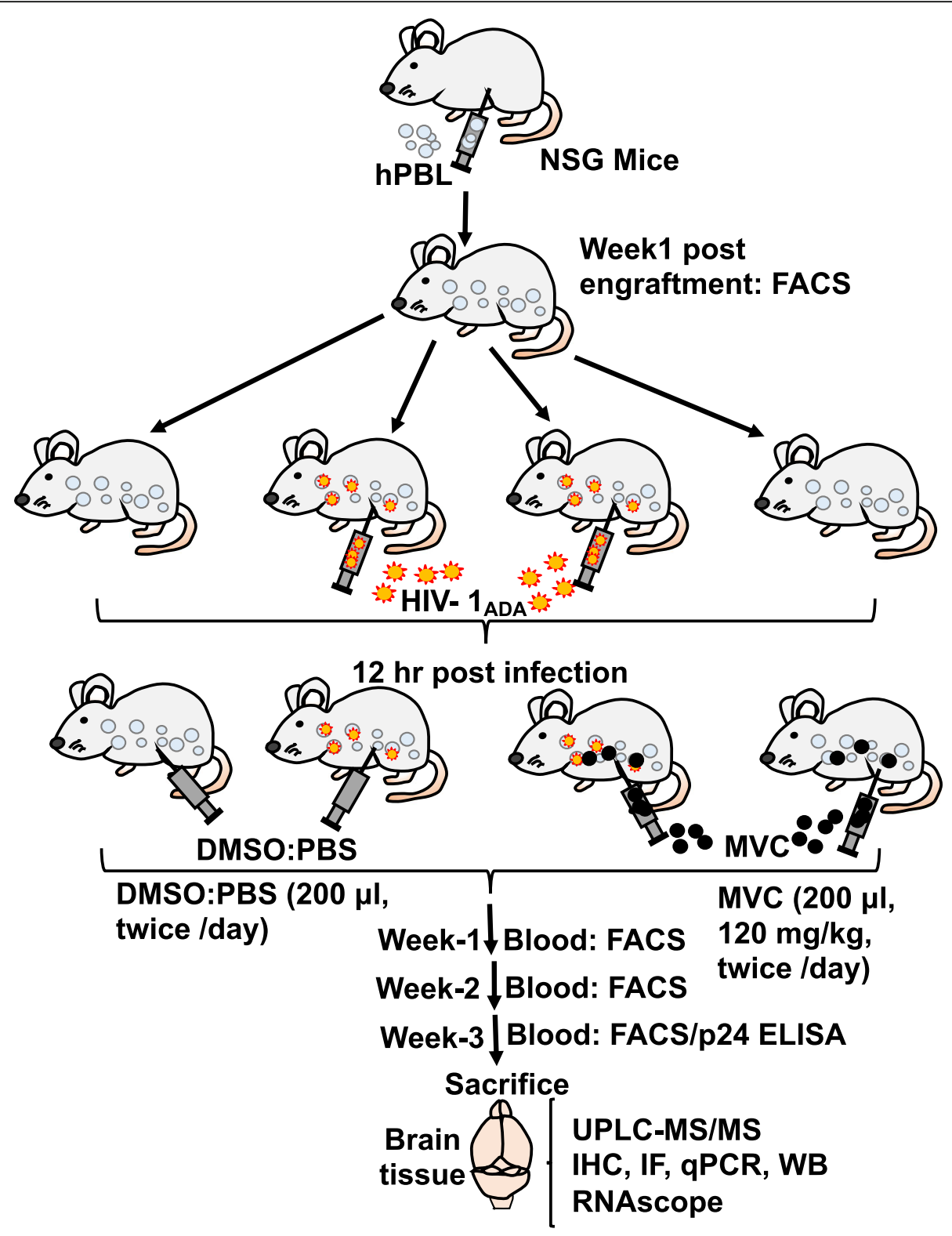

Fig. 1 Schematic representation of animals' engraftment, infection, treatment, samples collection, and analyses. Abbreviations: NSG: NOD/scid-IL-2RYc null; hPBL: human peripheral blood lymphocytes; FACS: fluorescence activated cell sorting; h: hours; MVC: maraviroc; DMSO: Dimethyl sulfoxide; PBS: phosphate-buffered saline; UPLC-MS/MS: ultraperformance liquid chromatography-tandem mass spectrometry; IHC: immunohistochemistry; IF: immunofluorescence; qPCR: quantitative (real-time) polymerase chain reaction; ELISA: enzyme-linked immunosorbent assay

pTau (Thr205) (cat \#ab254410) were from Abcam (Cambridge, MA). Antibodies for ZO-2 (cat \#71-1400) were from Invitrogen (Carlsbad, CA); Tau (cat \#46687S) and p-Tau (Thr181) (cat \#12885S) from Cell signaling Technologies (Danvers, MA).

\section{FACS analysis}

Human (hCD4+, hCD8+, hCD3+, and hCD45+) cells in animals' blood were quantified by FACS. Briefly, blood $(200 \mu \mathrm{l})$ collected in ethylenediaminetetraacetic acid (EDTA)-tubes were centrifuged $\left(543 \times \mathrm{g}, 8 \mathrm{~min}\right.$ at $\left.4{ }^{\circ} \mathrm{C}\right)$ and plasma was collected and cryopreserved. Cell pellets were resuspended in $50 \mu \mathrm{l}$ FACS buffer (PBS containing $2 \%$ fetal bovine serum) and transferred into $5 \mathrm{ml}$ polypropylene round-bottom tubes (BD Falcon, Franklin Lakes, NJ). An antibody cocktail $[20 \mu \mathrm{l}$ containing the following fluorochrome-conjugated human monoclonal antibodies: CD45-PE-Cy7, CD8-APC, CD3-Pacific blue, and CD4-FITC] was added to each sample, mixed, and incubated for $1 \mathrm{~h}$ on ice in the dark. One $\mathrm{ml}$ red blood cells lysis buffer (Roche) was then added to each sample. Samples were incubated for $5 \mathrm{~min}$ at room temperature (RT) and were centrifuged $\left(377 \times \mathrm{g}, 5 \mathrm{~min}\right.$ at $\left.4^{\circ} \mathrm{C}\right)$. Cell 
pellets were washed two to four times in FACS buffer (2 $\mathrm{ml}$ ), resuspended in $0.5 \mathrm{ml}$ PBS containing $2 \%$ paraformaldehyde, and analyzed using BD LSRII and FACSDiva 8.0 (BD Biosciences).

\section{HIV p24 ELISA}

Immediately following animal sacrifice, blood was collected by cardiac puncture into EDTA tubes, and plasma was obtained by centrifugation $\left(543 \times \mathrm{g}, 8 \mathrm{~min}\right.$ at $\left.4{ }^{\circ} \mathrm{C}\right)$ and cryopreserved. HIV-1 p24 antigen levels in each plasma sample $(100 \mu \mathrm{l})$ were quantified using Quantikine HIV-1 group-specific antigen (Gag) p24 immunoassay kit (R\&D Systems, Minneapolis, MN) per the manufacturer's protocol; with optical density readings at $450 \mathrm{~nm}$ and wavelength corrections at $540 \mathrm{~nm}$, using a SpectraMax M5 (Molecular Devices, San Jose, CA). Standard curves from HIV-1 Gag p24 antigen standards were used to quantify each sample's p24 antigen levels.

\section{Human monocyte-derived macrophage (MDM) culture}

Monocytes were obtained by countercurrent centrifugal elutriation of leukopheresis packs from HIV-1, -2 and hepatitis-B seronegative donors, and MDM obtained as previously described [34, 37]. Briefly, freshly elutriated monocytes (2 million cells per well in 6-well plates) were differentiated into MDM by culture for 7 days in Dulbecco's Modified Eagle's Medium (DMEM, Sigma, St. Louis, MO) supplemented with $10 \%$ heat-inactivated pooled human serum, $1 \%$ glutamine, $50 \mu \mathrm{g} / \mathrm{ml}$ gentamicin, $10 \mu \mathrm{g} / \mathrm{ml}$ ciprofloxacin (Sigma), $1000 \mathrm{U} / \mathrm{ml}$ highly purified recombinant human macrophage colony stimulating factor. MDM were cultured as we previously described [34, 37] and all reagents were prescreened for endotoxin $(<10 \mathrm{pg} /$ $\mathrm{ml}$, Associates of Cape Cod, Woods Hole, MA) and mycoplasma contamination (Gen-probe II, Gen-probe, San Diego, CA).

\section{MDM HIV-1 infection and $A \beta$ treatment}

For infection, MDM were cultured in media containing HIV-1 (multiplicity of infection: 0.01) for $4 \mathrm{~h}$, washed 3 times with serum-free media and cultured for $24 \mathrm{~h}$. MDM A $\beta$ uptake was performed as previously described [38]. Briefly, infected and non-infected MDM were cultured for $1 \mathrm{~h}$ in media containing human $\mathrm{A} \beta$ (amino acid 1-42) (A $\beta-42)$ peptide (Invitrogen) dissolved in DMSO, at $10 \mu \mathrm{M}$ as previously reported [38], washed 3 times with serum-free media, and cultured again for $24 \mathrm{~h}$ with or without MVC $(2.5$ or $5 \mu \mathrm{M})$. Controls included MDM treated with DMSO (vehicle). Culture supernatants were collected at $24 \mathrm{~h}$ and any cell debris removed by centrifugation $\left(1000 \mathrm{x} \mathrm{g}\right.$ for $10 \mathrm{~min}$ at $\left.4{ }^{\circ} \mathrm{C}\right)$. Cells were harvested by trypsinization, washed three times with PBS, and lysed using CelLytic ${ }^{\text {ma }} M$ reagent (Sigma). Cell lysates and culture supernatants were used for A $\beta$-42 ELISA.

\section{Human brain microvascular endothelial cells (HBMEC) culture}

Primary HBMEC were isolated from brain tissue obtained during surgical removal of epileptogenic cerebral cortex in adult patients, under an Institutional Review Board-approved protocol as previously described [37, 39]. Routine evaluation by immunostaining for vonWillebrand factor, Ulex europaeus lectin and CD31 showed that cells were $>99 \%$ pure. Freshly isolated cells were cultured in collagen-coated flasks or 6-well culture plates using DMEM/F12 (Life Technologies, Grand Island, NY, USA) containing $10 \%$ fetal bovine serum (Atlanta Biologicals, Flowery Branch, GA) supplemented with $10 \mathrm{mM}$ L-glutamine (Life Technologies), 1\% heparin (Thermo Fisher Scientific, Pittsburgh, PA), 1\% endothelial cell growth supplement (BD Bioscience, San Jose, CA), 1\% penicillin-streptomycin (Life Technologies), and 1\% fungizone (MP Biomedicals, Solon, $\mathrm{OH}$ ). Cells at passage 2 to 4 were used in this study.

\section{HBMEC $A \beta$ treatment}

Confluent HBMEC plated on collagen-coated six-well plates were treated with human $A \beta-42$ peptide $(10 \mu \mathrm{M})$, with or without MVC $(5 \mu \mathrm{M})$ for $48 \mathrm{~h}$, and LRP1 and RAGE levels in endothelial cells lysates quantified by immunoblotting. In separate experiments, HBMEC were cultured to confluence on collagen-treated tissue culture inserts $(0.4-\mu \mathrm{m}$ pore size; Corning, Lowell, MA) as we previously described $[2,40]$. Human $A \beta-42$ peptide $(10 \mu \mathrm{M})$ was added to the upper chamber of the transwell system in the presence or absence of MVC (2.5 or $5 \mu \mathrm{M})$ and/or high affinity antagonists for LRP1 (500 nM, Kerafast, Boston, MA) and RAGE (200 nM, Tocris, Minneapolis, MN) (30 min pre-treatment). These inhibitors concentrations were selected based on previously published studies [41] and manufacturers' data showing that these antagonists concentrations blocked secretase activity and $A \beta$ binding to LRP1 and RAGE without causing cellular toxicity. Controls included HBMEC treated with DMSO (vehicle). After $24 \mathrm{~h}$ culture, media in the transwell lower chamber were collected and any cell debris removed by centrifugation (1000 x g for 10 min at $4{ }^{\circ} \mathrm{C}$ ). HBMEC in the transwell upper chamber were harvested by trypsinization, washed three times with PBS, and lysed. Cell lysates and culture supernatants were used for $\mathrm{A} \beta-42$ ELISA.

\section{Amyloid- $\beta$ ELISA}

Levels of $A \beta-42$ in animals plasma samples $(100 \mu \mathrm{l})$ were quantified using the mouse $A \beta(1-42)$ ELISA kit (Novus Biologicals, Centennial, $\mathrm{CO}) ; \mathrm{A} \beta-42$ levels in human MDM and HBMEC culture supernatants and cell lysates $(100 \mu \mathrm{l})$ were quantified using the human $\mathrm{A} \beta(1-42)$ Quantikine ELISA kit (R\&D Systems), according to the 
manufacturers' protocols. Standard curves from mouse and human $A \beta(1-42)$ reference standards (provided with each kit) were used respectively to quantify $A \beta-42$ levels in plasma, MDM, and HBMEC samples.

\section{Immunohistochemistry}

Following animal sacrifice, brain tissues (half of a brain lobe including the frontal cortex) were rinsed with PBS, fixed in $4 \%$ paraformaldehyde (overnight at $4{ }^{\circ} \mathrm{C}$ ), kept in $70 \%$ ethanol for $24 \mathrm{~h}$ and paraffin-embedded using a Shandon Citadel 1000 tissue processor (ThermoFisher Scientific, Waltham, MA). Paraffin blocks were stored at RT and cut into $5 \mu \mathrm{m}$ sections using a Leica RM2235 microtome (Leica Biosystems, Buffalo Grove, IL). Tissue sections were incubated for 20 to $30 \mathrm{~s}$ in a water bath $\left(38^{\circ} \mathrm{C}\right)$, mounted on Superfrost Plus microscope slides (Fisher Scientific) and dried at RT overnight. For antigen retrieval, slides were dried for $1 \mathrm{~h}$ at $60^{\circ} \mathrm{C}$ in a standard incubator (Lab-Line 403, ThermoFisher), cooled at RT for $10 \mathrm{~min}$, placed in a tray containing $300 \mathrm{ml}$ of Trilogy solution (Cell Marque, Rocklin, CA) and incubated for $15 \mathrm{~min}$ under high pressure using a pressure cooker (Cuisinart CPC-600) containing $700 \mathrm{ml}$ water as well as a 2nd tray containing $300 \mathrm{ml}$ Trilogy. Following the 15 min high-pressure incubation, slides were transferred to the 2nd Trilogy tray inside the cooker, gently agitated, incubated for $5 \mathrm{~min}$, and washed 5 times with deionized water, with each wash consisting of 3 min incubation in deionized water at RT. Slides were then transferred to a tray containing $300 \mathrm{ml}$ PBS with $0.1 \%$ Tween-20 (PBST), incubated for $5 \mathrm{~min}$ at RT and for $30 \mathrm{~min}$ (RT) in PBST containing 10\% normal goat serum (Vector, Burlingame, CA) to block non-specific sites. Slides were then incubated overnight $\left(4{ }^{\circ} \mathrm{C}\right)$ with primary antibodies in PBST at the following dilutions: HLA-DR (1:100), claudin-5 (1: 250), NeuN (1:100), MAP 2 (1:3500), A $\beta 1-42$ (1:500), Tau (1:500), and phospho-Tau (1:100). Control antibodies included isotope-matched IgG.

Following incubation with primary antibodies, slides were washed 3 times with PBST at RT ( 5 min for each wash), incubated for $1 \mathrm{~h}$ at RT with polymer-based horseradish peroxidase (HRP)-conjugated EnVision mouse or rabbit secondary antibodies (Dako, Carpinteria, CA) and washed 3 times with PBST. Slides were developed with 3,3'-diaminobenzidine (DAB; Dako), counter-stained with hematoxylin (for $30 \mathrm{~s}$ ), washed three times with deionized water, dipped for $10 \mathrm{~s}$ in ammonia $(0.037 \mathrm{~mol} / \mathrm{l})$ and rinsed three times with deionized water. Slides were dehydrated by sequential incubation (5 min, RT) in ethanol: in 80\% (once), 95\% (once), and 100\% (twice) ethanol. Dehydrated slides were washed ( $5 \mathrm{~min}, \mathrm{RT}$ ) twice in xylene, air dried for $2 \mathrm{~min}$, and mounted using Cytoseal-60 (ThermoFisher). A coverslip was then placed over each tissue, avoiding the formation of air bubbles.

Images were captured using a Nikon Eclipse E800 microscope, Infinity-1(IFN 1-5C) camera (Luminera, Ontario, Canada) and the Infinity Analyze software. Quantitative analysis of HLA-DR+ cells was performed using the computer-assisted image analysis of the MetaMorph software (Molecular Devices, San Jose, CA). For each mouse, ten fields-of-view (FOV) were analyzed and normalized to surface area to estimate the number of HLA-DR+ cells per $\mu \mathrm{m}^{2}$ of FOV. Semi-quantitative analysis of claudin-5, NeuN, MAP 2, A $\beta$, Tau, and phospho-Tau expression (staining intensity and surface area occupied by immunostaining) was performed using the MetaMorph software. For each mouse, ten FOV were analyzed, the staining intensity was normalized to surface area $\left(\mu \mathrm{m}^{2}\right)$ and averaged to estimate the protein expression $\left(\mu \mathrm{m}^{2}\right.$ FOV). Coronal sections from the somatosensory regions of the cerebral cortex were used for all histology, except for Tau and pTau where we used coronal sections from the hippocampus fimbria (Supplemental Fig. 1) because pTau were mostly concentrated in this region.

\section{RNAscope assay}

This assay was performed using RNAscope ${ }^{\circ} 2.5$ Assay kit (ACD Biotech, Newark, CA) according to the manufacturer's protocol. Briefly, $5 \mu \mathrm{m}$ paraffin-embedded brain tissue (frontal cortex) sections were mounted onto slides, air dried overnight, and baked for $1 \mathrm{~h}$ at $60^{\circ} \mathrm{C}$ in a standard incubator. Baked tissues were immediately deparaffinized by washing ( 5 min incubation at RT) three times with xylene, incubated for $1 \mathrm{~min}$ in $100 \%$ ethanol, and dried at RT for $5 \mathrm{~min}$. Tissues were incubated for $10 \mathrm{~min}$ (RT) in hydrogen peroxide, $15 \mathrm{~min}$ in RNAscope target retrieval buffer heated to $99^{\circ} \mathrm{C}$, rinsed in distilled water, and incubated for $3 \mathrm{~min}$ (RT) in 100\% ethanol. Slides were then air-dried and kept on an HybEZ rack (ACD Biotech) placed in a humidified chamber. RNAscope protease plus solution was added to tissues and slides incubated for $30 \mathrm{~min}$ at $40^{\circ} \mathrm{C}$ in the HybEZ oven (ACD Biotech), washed in distilled water, treated with 78-ZZ HIV RNA specific probe (ACD Biotech), incubated again at $40^{\circ} \mathrm{C}$ for $2 \mathrm{~h}$, and washed three times with the wash buffer provided with the kit. Detection of RNA-specific probes hybridized to target viral RNA was done by sequential hybridization with HRP-labeled probes and chromogenic detection using the DAB system, with hematoxylin counterstaining and ethanol dehydration. Dehydrated slides were washed ( $5 \mathrm{~min}, \mathrm{RT}$ ) twice in xylene, air dried for $2 \mathrm{~min}$, and mounted using Cytoseal-60 and a coverslip. Images were captured using a Nikon Eclipse E800 microscope, Infinity-1(IFN 1-5C) camera (Luminera, Ontario, Canada) and the Infinity Analyze software. Quantitative analysis of RNA copies 
was performed using a computer-assisted image analysis of the MetaMorph software. The total number of viral RNA in each cluster was calculated by area normalization. For each mouse, ten FOV were analyzed and averaged to estimate HIV RNA copy number per $\mu \mathrm{m}^{2}$ of FOV.

\section{Immunofluorescence}

OCT-embedded brain tissue sections $(10 \mu \mathrm{m})$ were mounted onto Superfrost Plus slides, fixed in $4 \%$ formaldehyde (20 min, RT), dried (10 min), washed in PBS (5 min, RT), and incubated ( $1 \mathrm{~h}, \mathrm{RT})$ in PBS containing $3 \%$ bovine serum albumin and $0.1 \%$ triton X100 to block non-specific bindings. Slides were then incubated overnight $\left(4^{\circ} \mathrm{C}\right)$ with primary antibodies in blocking solution, at the following dilutions: NFL (1:4000), ZO-1 (1:1000), and ZO-2 (1:500). Following incubation with primary antibodies, slides were washed $(5 \mathrm{~min}, \mathrm{RT})$ three times with PBS, incubated ( $1 \mathrm{~h}$ in the dark at RT) with secondary antibodies conjugated to Alexa Fluor-488 (diluted 1: 5000 in blocking solution), washed five times with PBS, and mounted in Prolong Gold anti-fade reagent containing DAPI (Molecular Probes, Grand Island, NY). Images were captured using an Eclipse TE20000-U fluorescent microscope (Nikon, Melville, NY) and Infinity 3-6urfm monochrome camera (Luminera). Semi-quantitative analysis of NFL, ZO-1, and ZO-2 expression was performed using computer-assisted image analysis of the MetaMorph software. For each mouse, ten FOV were analyzed, the staining intensity was normalized to surface area $\left(\mu \mathrm{m}^{2}\right)$ and averaged to estimate the protein expression $\left(\mu \mathrm{m}^{2} \mathrm{FOV}\right)$.

\section{Ultraperformance liquid chromatography-tandem mass spectrometry (UPLC-MS/MS)}

MVC levels in animals' plasma and brain tissues (cerebrum) were quantified by UPLC-MS/MS as previously described [42]. For plasma, $50 \mu \mathrm{l}$ of each plasma sample was added to $10 \mu \mathrm{l}$ of a $1 \mu \mathrm{g} / \mathrm{ml}$ indinavir free base as internal standard (IS) and $1 \mathrm{ml}$ of ice-cold MS-grade acetonitrile. For brain tissue, $100 \mathrm{mg}$ of each tissue sample was homogenized in four volumes of MS-grade water; $1 \mathrm{ml}$ ice-cold acetonitrile containing $10 \mu \mathrm{l}$ of IS was then added. Both plasma and brain samples were vortexed for $3 \mathrm{~min}$ and centrifuged $(16,000 \times \mathrm{g}$ for $10 \mathrm{~min}$, $4{ }^{\circ} \mathrm{C}$ ). One $\mathrm{ml}$ of supernatant was evaporated to dryness under vacuum and dried samples reconstituted in $100 \mu \mathrm{l}$ of $50 \%$ MS-grade methanol in water. Samples were centrifuged $\left(16,000 \times \mathrm{g}\right.$ for $\left.10 \mathrm{~min}, 4^{\circ} \mathrm{C}\right)$ and $40 \mu \mathrm{l}$ of supernatant was used for analysis.

Chromatographic separation was performed using a Waters ACQUITY UPLC (Milford, MA) system coupled with a Sciex QTRAP 4500 triple quadrupole linear ion trap hybrid mass spectrometer, with an electrospray ionization source (Applied Biosystems /MDS Sciex, Foster City, CA). For separation, an ACQUITY BEH Shield RP18 column $(1.7 \mu \mathrm{m}, 2.1 \times 100 \mathrm{~mm})$ equipped with an ACQUITY Vanguard BEH Shield precolumn $(1.7 \mu \mathrm{m}$, $2.1 \times 5 \mathrm{~mm}$ ) was employed, using a stepwise gradient of $7.5 \mathrm{mM}$ ammonium acetate, $\mathrm{pH} 5$ for mobile phase A and acetonitrile for mobile phase $\mathrm{B}$. The gradient was held at 70\% mobile phase A for $3 \mathrm{~min}$, decreased to $40 \%$ mobile phase A over $90 \mathrm{~s}$ and held for $30 \mathrm{~s}$, decreased to $5 \%$ mobile phase A over $30 \mathrm{~s}$ and held for $30 \mathrm{~s}$, increased to $70 \%$ mobile phase A over $15 \mathrm{~s}$ and held for $105 \mathrm{~s}$ prior to next sample injection at a flow rate of $0.25 \mathrm{ml} / \mathrm{min}$. The injection volume for each sample was $10 \mu$ l. Detection was achieved in the positive ionization mode using the following transitions: $\mathrm{m} / \mathrm{z}$ MVC 514/280; $\mathrm{m} / \mathrm{z}$ indinavir 614/421. Calibration standards consisted of 0.2 to $2000 \mathrm{ng} / \mathrm{ml}$ MVC with $100 \mathrm{ng} / \mathrm{ml}$ indinavir for both plasma and brain homogenates and the ratio of analyte to IS peak area was used for quantitation of unknowns.

\section{RNA isolation and real-time PCR}

Total RNA was extracted from brain tissues using Trizol reagent (Life Technologies-Ambion, Austin, TX) according to the manufacturer's protocol. RNA yield and quality were checked using a NanoDrop spectrophotometer (NanoDrop Technologies, Wilmington, DE) and for all samples, absorbance ratios of $260 / 280$ were $\geq 2$. Reverse transcription was performed using Verso cDNA synthesis kit (ThermoFisher); $1 \mu \mathrm{g}$ RNA in $11 \mu \mathrm{l}$ of nucleasefree water was mixed with $4 \mu \mathrm{l}$ of $5 \mathrm{X}$ cDNA synthesis buffer, $2 \mu \mathrm{l}$ dNTP mix, $1 \mu \mathrm{l}$ random hexamers, $1 \mu \mathrm{l}$ reverse transcriptase enhancer and $1 \mu \mathrm{l}$ Verso enzyme mix. Amplification conditions were: 1 cycle of $42^{\circ} \mathrm{C}$ for 30 min, followed by $95^{\circ} \mathrm{C}$ for $2 \mathrm{~min}$.

Quantitative real-time PCR was performed using the 384well block of a LightCycler 480 II (Roche) Real-Time PCR System. For each reaction, $500 \mathrm{ng}$ of cDNA in $5 \mu \mathrm{l}$ nucleasefree water was mixed with $3 \mu \mathrm{l}$ PCR grade water, $10 \mu \mathrm{l}$ of $2 \mathrm{X}$ LightCycler 480 Probe master mix, and $1 \mu \mathrm{l}$ of 20X TaqMan primer-probe mix. Cycling conditions were as follows: $95^{\circ} \mathrm{C}$, 5 min with a ramp rate of $4.8^{\circ} \mathrm{C} / \mathrm{s}$; followed by 45 cycles of $95^{\circ} \mathrm{C}, 10 \mathrm{~s}, 4.8^{\circ} \mathrm{C} / \mathrm{s} ; 60^{\circ} \mathrm{C}, 15 \mathrm{~s}, 2.5^{\circ} \mathrm{C} / \mathrm{s}$; and $72^{\circ} \mathrm{C}, 1 \mathrm{~s}$, $4.8^{\circ} \mathrm{C} / \mathrm{s}$; and hold at $40^{\circ} \mathrm{C}, 10 \mathrm{~s}, 2^{\circ} \mathrm{C} / \mathrm{s}$. Standard curves were generated from $\mathrm{ACH}-2$ cells (an HIV-1 latent T-cell clone containing one integrated copy of proviral DNA per cell), and qPCR was used to quantify HIV-1 long-terminal repeat (LTR), polymerase (pol), transactivator of transcription (tat), and gag copy numbers in each sample. Results were further normalized to levels of human CD45+ cells in each brain tissue sample. MAP-2, NeuN, gamma-secretase activating protein (GSAP) and NFL mRNA levels were quantified using the delta-CT method as instructed in the Lightcycle 480 software manual and normalized to the sample's GAPDH levels. All primers were obtained from Applied Biosystems, and 
primers' IDs were as follows: LTR (AIWR3QG), pol (AIY9Z2W), tat (AIX01W0), gag (AIo1X84), CD45 (Hs04189704), MAP-2 (Mm00485231), NFL (Mm01315666_ m1), NeuN (Mm01248771_m1), GSAP (Mm00615236_m1) and GAPDH (Mm99999915_g1).

\section{Western blot analysis}

Each brain tissue sample ( $5 \mathrm{mg}$ ) was transferred into a tube containing $500 \mu \mathrm{l}$ of ice-cold tissue lysis buffer (50 $\mathrm{mM}$ Tris- $\mathrm{HCl}, 150 \mathrm{mM} \mathrm{NaCl}, 0.25 \%$ SDS, $0.25 \%$ Sodium Deoxycholate, $1 \mathrm{mM}$ EDTA) and $5 \mu \mathrm{l}$ of $100 \mathrm{X}$ protease and phosphatase inhibitor cocktail, placed on ice and homogenized using a motor and pestle. Homogenized samples were incubated for $30 \mathrm{~min}$ on ice, with intermittent vortex (every 5 to $6 \mathrm{~min}$ ) for $10 \mathrm{~s}$. Samples were centrifuged for $10 \mathrm{~min}$ at $18000 \times \mathrm{g}, 4^{\circ} \mathrm{C}$; and each supernatant transferred into a fresh pre-chilled tube and stored at $-80^{\circ} \mathrm{C}$ until use. Total protein levels in each sample were quantified using the bicinchoninic acid assay (ThermoFisher), and $30 \mu \mathrm{g}$ protein analyzed by sodium dodecyl sulfate-polyacrylamide gel electrophoresis as previously described $[34,43]$ using monoclonal antibodies to claudin-5, ZO-1, ZO-2, MAP 2, NeuN, NFL, LRP1, RAGE, A $11-42$, Tau, pTau (Thr181), pTau (Ser396), pTau (Ser199), pTau (Thr231), pTau (Thr205), and $\beta$-actin (each at 1:1000 dilution). To confirm equal loading, protein expression in each sample was normalized to the sample's $\beta$-actin levels, and pTau normalized to the sample's total Tau levels. The original Western blot images are included in "Additional File-1".

\section{Statistical analysis}

Data were analyzed by Student's t-test (two-tailed) or by one- or two-way analysis of variance followed by Tukey's multiple-comparisons tests using GraphPad Prism 7.05 (GraphPad Software, La Jolla, CA, USA). Data are presented as mean \pm standard deviation (SD) and the threshold of significance level was 0.05 .

\section{Results \\ MVC reduced HIV-induced immunosuppression in infected animals}

HIV infection is known to decrease CD4+ T-cells and increase CD8+ T-cells $[44,45]$. To determine the effects of HIV infection and MVC treatment on the animals' immune system, we quantified blood levels of human (hCD45+, hCD3+, hCD4+, and hCD8+) cells in animals' blood before (pre) infection and at week-1, week-2, and week-3 p.i. The four animal groups showed no significant difference in mean hCD4+ cells pre-infection $(51.65 \pm 13.54(\mathrm{SD})$ to $52.85 \pm 12.54 \%)$ or at week-1 p.i. $(64.5 \pm 5.7$ to $70 \pm 16 \%)$ (Fig. $2 \mathrm{a}$ and b). At week-2 p.i., infected untreated animals (HIV) showed major immunosuppression compared to infected animals treated with MVC (HIV + MVC), non-infected controls (PBS), or non-infected animals treated with MVC (MVC). The mean number of hCD4+ T-cells in the HIV group was 8 -fold lower than in the PBS group $(P<0.0001), 6$-fold lower than in the HIV + MVC group $(\mathrm{P}<0.0001)$, and 7fold lower than in the MVC group $(\mathrm{P}<0.0001)$ (Fig. 2b). At week-3 p.i., the mean number of hCD4+ cells in the HIV group was 6.6-fold lower than in the PBS group $(P<0.0001)$, 4-fold lower than in the HIV + MVC group $(\mathrm{P}<0.0001)$, and 6.2-fold lower than in the MVC group $(\mathrm{P}<0.0001)$ (Fig. 2b). Thus, compared to untreated HIVinfected animals, infected animals treated with MVC showed 6-fold higher hCD4+ T-cells at week-2 and 4fold higher hCD4+ T- cells at week-3 p.i.

\section{MVC reduced HIV-induced increase in hCD8+ T-cells in infected animals}

Pre-infection mean levels of hCD8+ T-cells were not significantly different between the 4 animal groups $(28 \pm$ 5.7 to $30.4 \pm 8.66 \%$ ) (Fig. $2 \mathrm{c}$ and d). However, HIV infection resulted in increased hCD8+ T-cells, which was prevented by MVC treatment. At week-1 p.i., mean hCD8+ T-cells in infected animals were 1.8-fold higher than in infected mice treated with MVC or PBS control $(P<$ 0.0001), and 1.4-fold higher than hCD8+ T-cells in the MVC control group $(P=0.0013)$ (Fig. $2 c$ and $d)$. At week-2 p.i., mean hCD8+ T-cells in infected animals were 1.96-fold, 3-fold, and 2.1-fold higher than the mean hCD8+ T-cells in the HIV + MVC, PBS, and MVC groups, respectively $(P<0.0001$, Fig. $2 d)$. At week -3 p.i., mean hCD8+ T-cells in the HIV group were 2-fold, 3.76-fold, and 3.56-fold higher than mean hCD8+ Tcells in the HIV + MVC, PBS, and MVC groups, respectively $(P<0.0001$, Fig. $2 d)$.

\section{MVC increases hCD4+/hCD8+ T-cells ratios in infected animals}

Pre-infection, hCD4+/hCD8+ T-cells ratios were not significantly different between the 4 animal groups (1.82 to 1.94). HIV infection resulted in decreased hCD4/hCD8 ratios, which was abrogated by MVC treatment. Compared to infected untreated mice, infected mice treated with MVC, or PBS control had 2-fold higher hCD4/ hCD8 ratios at week-1 p.i. $(P=0.0004$, Fig. 2 e and $\mathrm{f})$. At week-2 p.i., compared to infected untreated mice, hCD4/ hCD8 ratios were 12.5-fold, 25.6-fold, and 15.5-fold higher in HIV + MVC, PBS, and MVC animal groups, respectively $(P<0.0001$, Fig. $2 \mathrm{f})$. At week-3 p.i., compared to infected untreated mice, $\mathrm{hCD} 4 / \mathrm{hCD} 8$ ratios were $9.2-$ fold, 25.78-fold, and 22.4-fold higher in HIV + MVC $(P=0.0007)$, PBS, and MVC groups $(P<0.0001)$, respectively (Fig. 2f). 


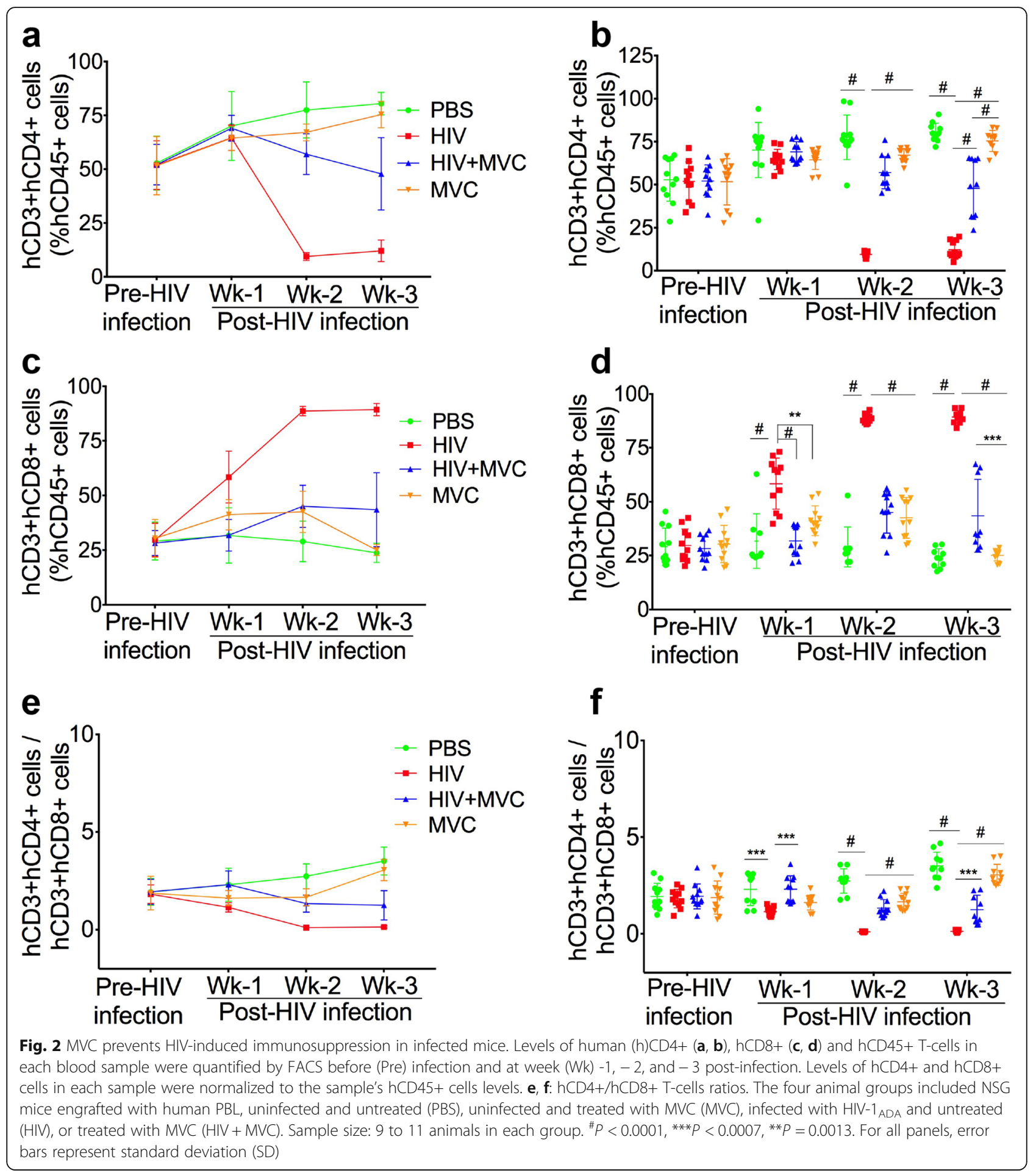

MVC enters the CNS and decreases systemic and brain viremia in infected animals

We performed UPLC-MS/MS quantification of MVC in plasma and brain tissues of mice treated with MVC (at week-3) as detailed in the Methods section. The mean MVC plasma levels were $117.5 \pm 120.6 \mathrm{ng} / \mathrm{ml}$ (range: 7.23 to $294 \mathrm{ng} / \mathrm{ml}$ ), and the mean MVC levels in brain tissues were $216.6 \pm 234 \mathrm{ng} / \mathrm{g}$ (range: 81 to $685 \mathrm{ng} / \mathrm{g}$ ). There was a positive correlation between plasma and brain MVC levels (Pearson $r=0.638$ ), but it did not reach statistical significance $(P=0.09)$.

RNAscope quantification of HIV in brain tissues showed high viral copy numbers in the brains of infected animals and MVC treatment decreased the brain viral loads by 
11.75-fold (Fig. 3a-c, $P<0.0001$, degree of freedom $(\mathrm{df})=$ 14, $F=258.6)$. qPCR quantification of viral genes also showed high levels of HIV-1 gag, pol, LTR and tat in brain tissues of infected animals, and MVC treatment significantly decreased the levels of each of these viral genes (Fig. 3d, P < 0.0001). Mean HIV-1 p24 antigen levels in the plasma of infected mice were $350 \pm 79 \mathrm{pg} / \mathrm{ml}$, and MVC treatment decreased plasma viral p24 levels by 2.5 -fold (mean p24: $141 \pm 37 \mathrm{pg} / \mathrm{ml}$ ) (Fig. $3 \mathrm{e}, \mathrm{P}<0.0001, \mathrm{df}=22$ ). Two-tailed t-tests were used for Fig. 3c-e.

\section{MVC blocked HIV-induced leukocyte infiltration into the brain}

Quantification of human (HLA-DR+) cells in animals' brain tissues showed significantly higher cellular infiltration in the brain of HIV-infected animals. Compared to non-infected controls (PBS or MVC groups), mean HLA-DR+ cells in the brain of HIV-infected animals were 2.3 to 2.58 -fold higher (Fig. 3f-h). MVC treatment (HIV + MVC) decreased HLA-DR+ cells in the brain of infected animals by 2.13 -fold compared to infected and non-treated animals (Fig. 3 h, $P<0.0001$ ).

\section{MVC prevented HIV-induced BBB alterations}

To assess the effects of HIV and MVC treatment on the $\mathrm{BBB}$ in vivo, we analyzed the expression of endothelial tight junction (TJ) proteins claudin-5 (Fig. 4a-d), ZO-1 (Fig. 4e-h), and ZO-2 (Fig. 4i-l) in animals' brain tissues. Immunohistochemistry and immunofluorescence analyses showed a decreased expression of claudin-5 (Fig. $4 \mathrm{a}$ and b), ZO-1 (Fig. 4e and f), and ZO-2 (Fig. 4i and j) in brain tissues of infected animals, and MVC prevented HIV-induced downregulation of these TJ proteins. Metamorph quantification of TJ proteins expression in all animals (9 to 11 mice in each group) showed that HIV-1 infection decreased claudin-5 expression by 5.2-fold (Fig. 4b, $\mathrm{P}<0.0001$ ) and decreased ZO-1 (Fig. 4f) and ZO-2 (Fig. 4j) expression by 3 -fold $(\mathrm{P}<0.0001)$ compared to PBS control. Compared to infected and non-treated animals, expression of claudin-5, ZO-1, and $\mathrm{ZO}-2$ in the $\mathrm{HIV}+\mathrm{MVC}$ group were increased, respectively, by 4fold (Fig. 4b), 2.7-fold (Fig. 4f), and 2.88-fold (Fig. 4j) $(P<0.0001)$. These results were confirmed by Western blot analyses (Fig. 4c, g and k) and densitometry quantification (Fig. 4d, h and 1). Data normalized to samples' actin levels showed that compared to the control PBS group, HIV-1 infection decreased the expression of claudin-5, ZO-1, and ZO-2, respectively, by 3.8-fold (Fig. 4d, $P=0.03$ ), 6.7-fold (Fig. 4h, $P=0.0005$ ) and 4.85-fold (Fig. 4l, $P=0.006)$. Compared to the HIV group, expression of claudin-5, ZO-1, and ZO-2 in the HIV + MVC group was increased, respectively, by 3.6-fold (Fig. 4d, $P=0.04$ ), 6.8-fold (Fig. 4h, $P=0.0004$ ) and 4.56-fold (Fig. 4l, $\mathrm{P}=0.03$ ).

\section{MVC reduced HIV-induced neuronal injury in infected animals}

To determine the effect of HIV infection and MVC on neuronal processes and phenotypes, we analyzed the expression of neuronal cytoskeletal (MAP 2), nuclei $(\mathrm{NeuN})$, and axonal (NF-L) markers in brain tissues. HIV infection decreased MAP 2 (Fig. 5a-e) and NeuN (Fig. 5f-j) expression, effects that were blocked by MVC treatment. Immunohistochemistry and metamorph quantification of MAP 2 and NeuN expression in brain tissues showed that compared to control animals (PBS or MVC groups), HIV-1 infection decreased MAP 2 (Fig. 5a and b) and NeuN (Fig. $5 \mathrm{f}$ and g) expression by 3.16-fold and 4.35-fold, respectively, and MVC treatment blocked HIV-induced downregulation of MAP 2 and NeuN. In the HIV + MVC group, MAP 2 (Fig. 5a and b) and NeuN (Fig. 5f and g) expression increased by 2.8 and 3.53-fold $(P<0.0001)$. Western blot analyses of brain tissues confirmed these findings. Compared to control animals, HIV-1 infection decreased MAP 2 (Fig. $5 \mathrm{c}$ and $\mathrm{d}$ ) and NeuN (Fig. 5h and i) expression by 3.8 and 15-fold, respectively; whereas in the HIV + MVC group, MAP 2 and NeuN expression increased by 3.2fold (Fig. $5 \mathrm{c}$ and d, $P<0.01$ ) and 10.6-fold (Fig. 5h and i, $P<0.001)$, respectively, compared to animals in the HIV group. qPCR also showed that HIV infection decreased MAP 2 mRNA levels by 90.7-fold (Fig. 5e, $P=0.011$ ) and decreased NeuN mRNA by 28.7-fold (Fig. 5j, $P=$ 0.004). In infected animals treated with MVC, MAP 2 and NeuN mRNA levels were increased by 46.8-fold (Fig. 5e $P=0.003$ ) and 25-fold (Fig. 5j, $P=0.015$ ), respectively, compared to levels in infected untreated animals.

Immunofluorescence and metamorph quantification showed that compared to control (PBS and MVC) groups, HIV infection decreased NFL expression by 4.75-fold (Fig. 6a and b; $P<0.0001$ ); and NFL levels in the HIV + MVC group were increased by 5 -fold compared to the HIV group (Fig. 6a and b, $\mathrm{P}<0.0001$ ). Western blot analyses also showed that HIV infection decreased NFL expression by 9.35-fold (Fig. 6c and d, $P<0.0001$ ), and MVC treatment increased NFL expression in infected animals by 4-fold compared to infected and untreated animals (Fig. $6 \mathrm{c}$ and $\mathrm{d}, \mathrm{P}=0.003$ ). HIV infection also decreased NFL mRNA levels in brain tissues by 29.5 -fold (Fig. 6e, $P=0.001$ ), and NFL mRNA levels in the HIV + MVC group were 11-fold higher than levels in infected untreated animals (Fig. 6).

\section{HIV-1 infection increased CNS and plasma $A \beta$ and increased CNS GSAP}

HAND is associated with AD-like pathology characterized by increased CNS A $\beta$ and Tau hyperphosphorylation [17-20]. Immunohistochemistry (Fig. 7a-c) and 


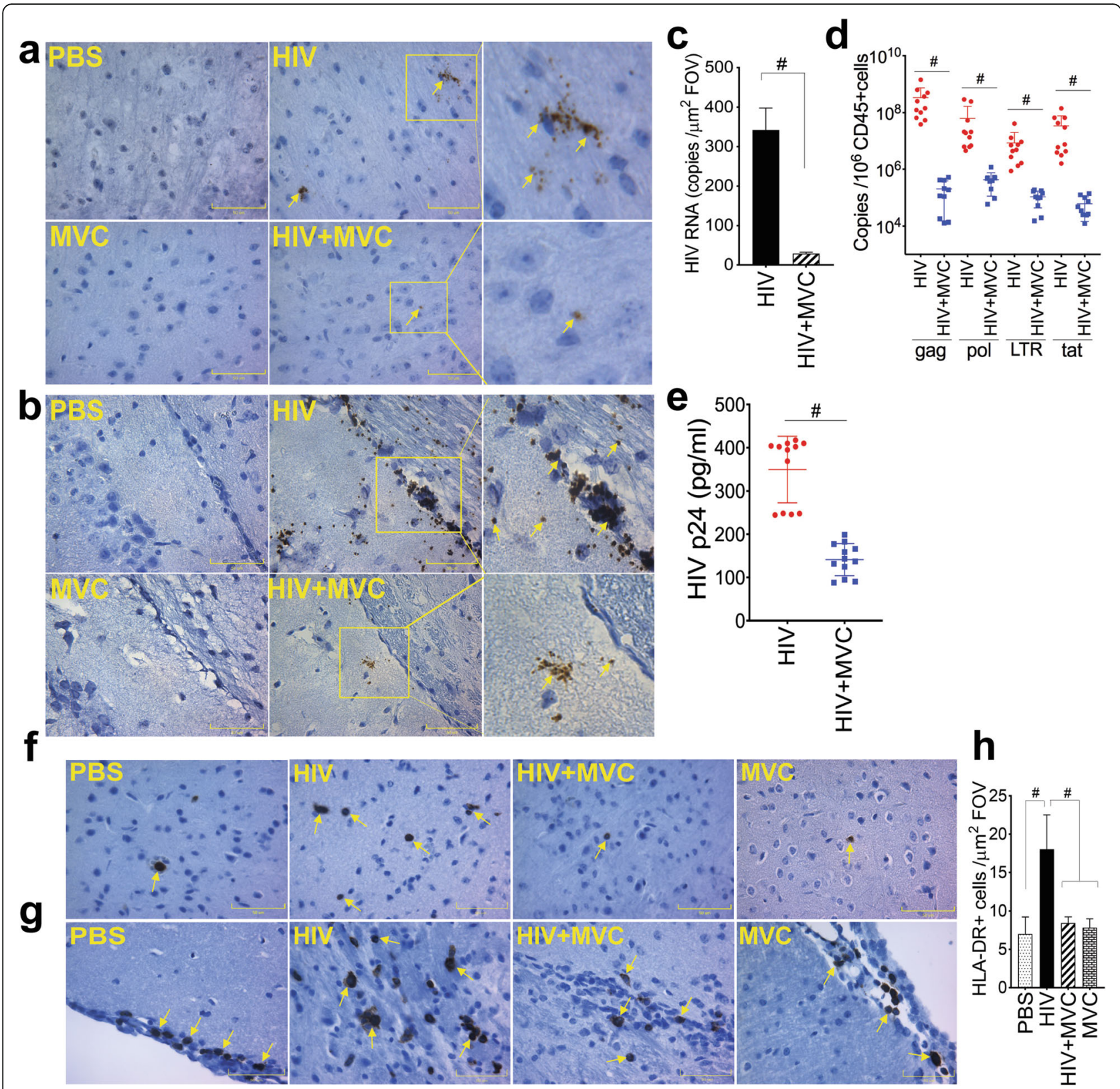

Fig. 3 MVC decreased viremia and abrogated HIV-induced cellular infiltration in the brain of infected animals. Brain HIV RNA copy (yellow arrows) numbers were quantified by RNAscope and, for each experimental group, representative images from the somatosensory cortex (a) and meningeal / somatosensory area layer 1 (b) are shown. c: Metamorph software was used to quantify HIV RNA copies numbers in all samples. For each animal brain sample, 10 random fields-of-view (FOV) were analyzed (5 FOV from the somatosensory cortex and 5 FOV from the meningeal / somatosensory area layer 1). d: Levels of HIV-1 gag, pol, LTR, and tat genes in brain tissues were quantified by qPCR and normalized to samples' hCD45+ cells levels. e: HIV-1 p24 antigen levels in plasma samples were quantified by ELISA. $\mathbf{f}, \mathbf{g}$ : HLA-DR expression in brain tissues was analyzed by immunohistochemistry and, for each experimental group, representative images from the somatosensory cortex $(\mathbf{f})$ and meningeal / somatosensory area layer $1(\mathbf{g})$ are shown. $\mathbf{h}$ : Metamorph was used to quantify HLA-DR+ cells in all brain samples and for each sample, 10 random FOV (5 FOV from the somatosensory cortex and 5 FOV from the meningeal / somatosensory area layer 1) were analyzed. For panels $\mathbf{a}, \mathbf{b}, \mathbf{f}$, and $\mathbf{g}$, images were at 40X. The four animal groups included PBS, HIV, HIV + MVC, and MVC; 9 to 12 animals in each group. \#P < 0.0001. Error bars represent SD

Western blot (Fig. 7d, e) analyses of brain tissues showed no $A \beta-42$ in control animals, but brain tissues from HIV-infected animals showed increased formation and accumulation of A $\beta-42$ (Fig. 7a-e). qPCR analyses of GSAP also showed that HIV-1 infection increased GSAP
mRNA in brain tissues by 13 to 15 -fold compared to control animal groups (Fig. 7f, $P<0.0001$ ). ELISA quantification of $A \beta-42$ in animals' plasma at week-3 p.i. showed that HIV infection increased plasma $A \beta-42$ levels by 3 -fold. Plasma A $\beta-42$ levels in HIV-infected 

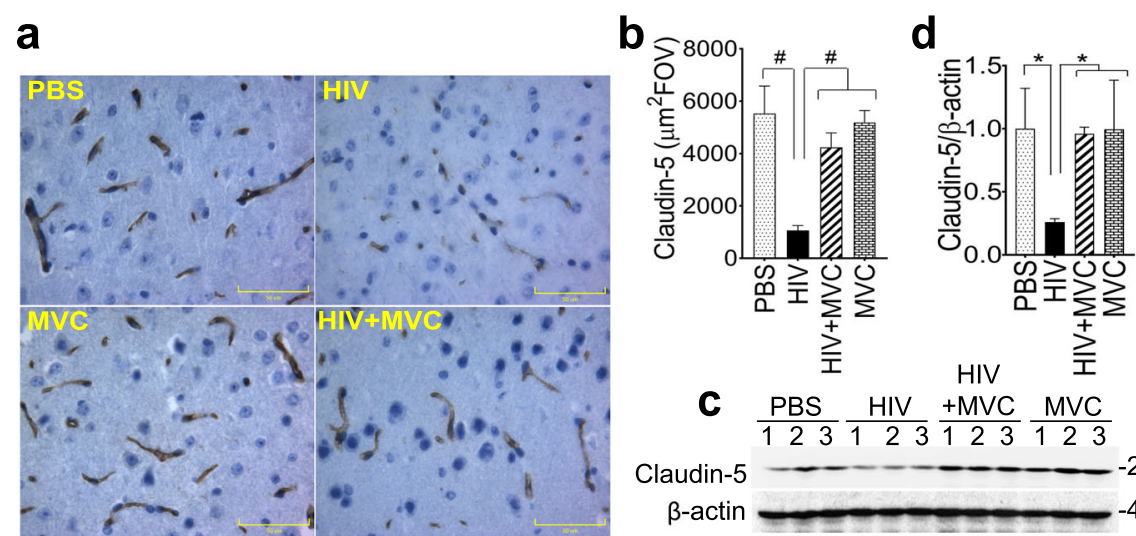

\section{C $\frac{\text { PBS }}{123} \frac{\text { HIV }}{123} \frac{+M V C}{123} \frac{\text { MVC }}{123}$}
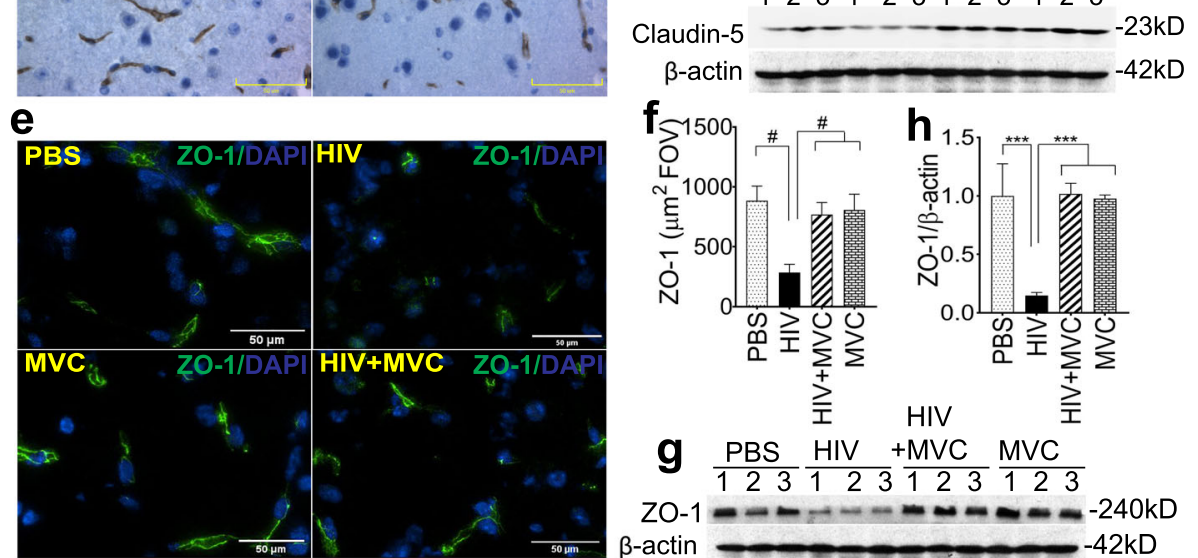

\section{$9 \frac{\mathrm{PBS}}{123} \frac{\mathrm{HIV}}{123}+\frac{\mathrm{MVC}}{123} \frac{\mathrm{MVC}}{123}$}
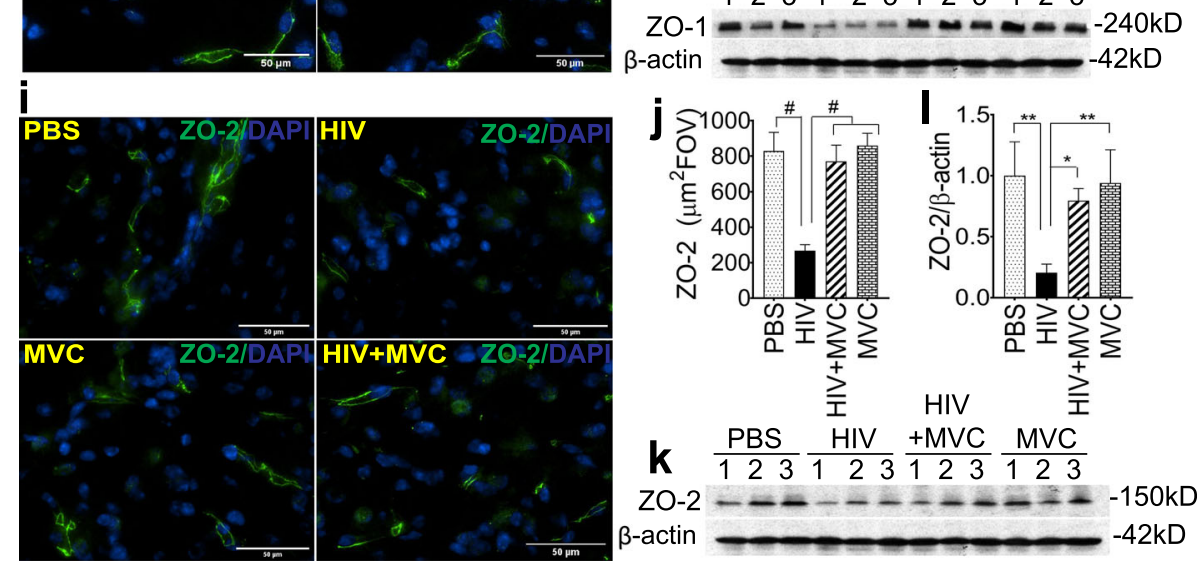

Fig. 4 MVC abrogated HIV-induced BBB alterations. Expression of brain endothelial tight junction proteins claudin-5 (a-d), ZO-1 (e-h), and ZO-2 (iI) were analyzed by immunohistochemistry $(\mathbf{a}, \mathbf{b})$ or immunofluorescence $(\mathbf{e}, \mathbf{f}, \mathbf{i}, \mathbf{j})$ with DAPI (blue) for nuclear counterstaining. Metamorph software was used to quantify claudin-5 (b), ZO-1 (f), and ZO-2 (j) levels in all samples; for each sample, 10 random FOV (from the somatosensory cortex) were analyzed. Western blot analyses $(\mathbf{c}, \mathbf{g}, \mathbf{k})$ and densitometry quantification normalized to sample's $\beta$-actin levels $(\mathbf{d}, \mathbf{h}, \mathbf{I})$ were also used to quantify claudin-5 (c, d), ZO-1 $(\mathbf{g}, \mathbf{h})$, and ZO-2 (k, l) levels in samples. For panels $\mathbf{a}, \mathbf{e}$, and $\mathbf{i}$, images were at 40X. The four animal groups included PBS, HIV, HIV + MVC, and MVC; 9 to 11 animals in each group. ${ }^{*} \mathrm{P}<0.0001$, ${ }^{*}{ }^{*} P<0.0005$, ${ }^{*} P<0.006,{ }^{*} P<0.05$. Error bars represent SD

animals were $137 \pm 52 \mathrm{pg} / \mathrm{ml}$ compared to $45.7 \pm 13.5 \mathrm{pg} /$ $\mathrm{ml}$ in control PBS animals $(P=0.0005$, Fig. $7 \mathrm{~g})$.

MVC reduced HIV-induced GSAP and CNS A $\beta$ formation, but increased plasma $A \beta$ levels

qPCR showed that MVC treatment of infected animals reduced GSAP mRNA levels in brain tissues by 3-fold compared to animals in the HIV group (Fig. 7f, $P=$ 0.0008). Immunohistochemistry analyses showed that compared to infected (HIV group) animals, MVC treatment (HIV + MVC group) reduced A $\beta-42$ levels by 4.26- fold [Fig. 7a-c, $P<0.0001 ; \mathrm{df}=14 ; \mathrm{F}=2.57$ ]. Western blot analyses confirmed these findings and showed that MVC treatment of infected animals reduced $A \beta-42$ levels by 3 -fold (Fig. $7 \mathrm{~d}$ and e, $P=0.0009$; $\mathrm{df}=4, \mathrm{~F}=$ 21.49) compared to animals in the HIV group. Twotailed t-tests were used for Fig. 7c and e. For animals in the PBS and MVC groups, immunohistochemistry (Fig. 7a-c) and Western blot (Fig. 7d, e) analyses showed no detectable $A \beta-42$ in brain tissues. Surprisingly, plasma A $\beta$-42 levels in HIV-infected and MVC-treated animals were 1.67 -fold higher $(228.6 \pm 74.3 \mathrm{pg} / \mathrm{ml})$ than in 

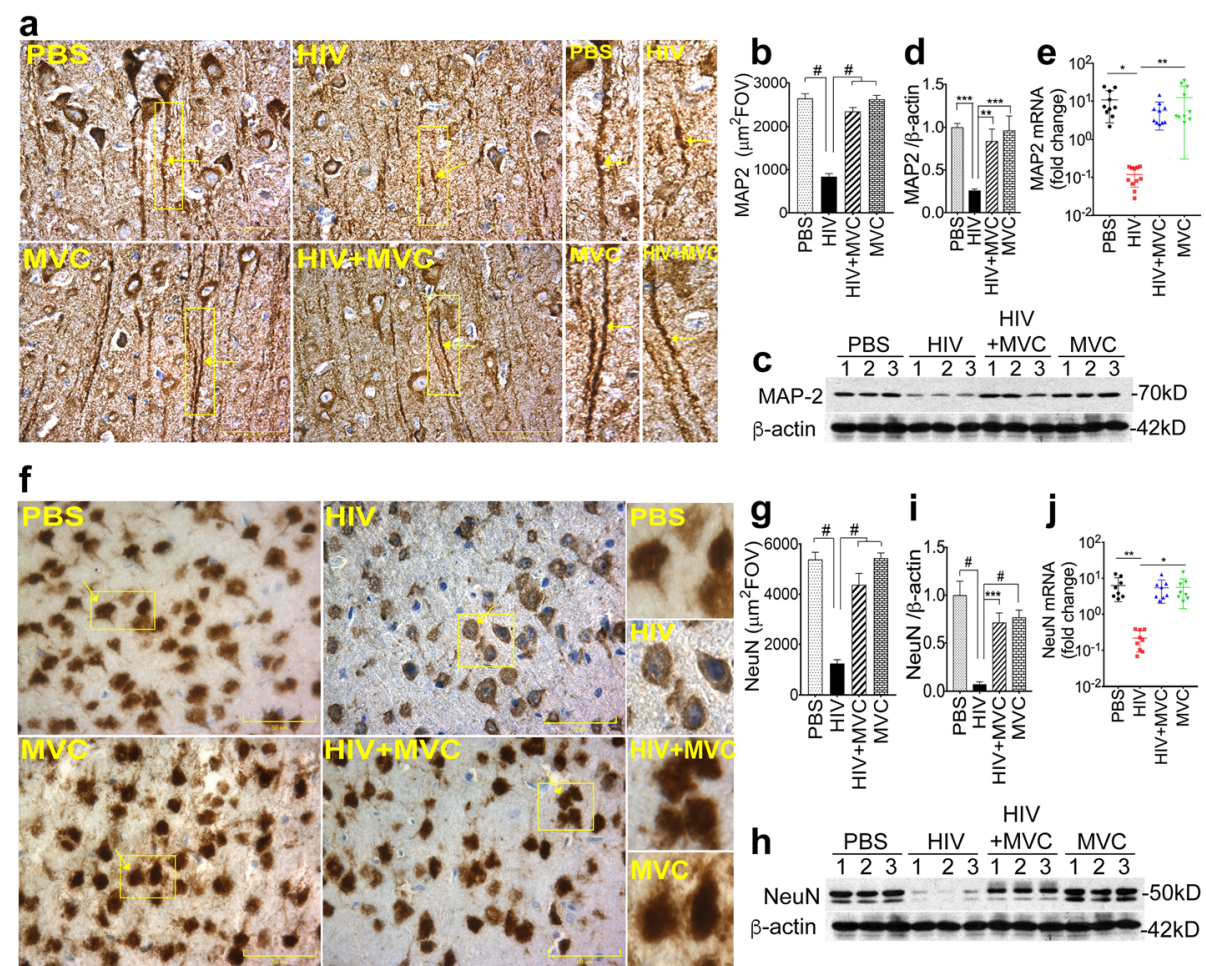

Fig. 5 MVC prevented HIV-induced downregulation of the neuronal markers MAP 2 and NeuN. a: Immunohistochemistry analyses of MAP 2 expression in brain tissues (somatosensory cortex). b: Metamorph quantification of MAP 2 expression in all samples. MAP 2 levels in brain tissues were also quantified by Western blot (c) followed by densitometry quantification normalized to sample's $\beta$-actin levels (d). f. immunohistochemistry analyses of NeuN expression in brain tissues (somatosensory cortex). g: Metamorph quantification of NeuN in all samples. NeuN levels in brain tissues were also quantified by Western blot (h) followed by densitometry quantification normalized to sample's $\beta$-actin levels (i). MAP 2 (e) and NeuN (j) mRNA levels in brain tissues were quantified by realtime PCR. For panels $\mathbf{a}$ and $\mathbf{f}$, images were at 40X. For panels $\mathbf{b}$ and $\mathbf{g}, 10$ random FOV analyzed for each sample. The four animal groups included PBS, HIV, HIV + MVC, and MVC; 9 to 11 animals in each group. ${ }^{\#} P<0.0001,{ }^{* *} P<0.0003$, ${ }^{* *} P<0.004$, ${ }^{*} P<0.015$. Error bars represent SD

infected non-treated animals (Fig. 7g, $\mathrm{P}=0.0005$ ), 5-fold higher than in control PBS group, and 5.7-fold higher than in the control MVC group $(40 \pm 11.6 \mathrm{pg} / \mathrm{ml})$ (Fig. $7 \mathrm{~g}, P<0.0001)$.

\section{HIV-1 infection increased CNS tau phosphorylation}

Immunohistochemistry (Fig. 8a-d) and Western blot (Fig. $8 \mathrm{e}-\mathrm{k}$ ) analyses of brain tissues showed similar levels of total Tau protein in all animal groups. Analyses of pTau normalized to total Tau showed that HIV-1 infection increased Tau phosphorylation at Thr181 by 8.5 to 11 -fold (Fig. $8 \mathrm{e}$ and f; $P=0.002$ ), at Ser396 by 18 to 22 -fold (Fig. $8 \mathrm{~g}$ and $\mathrm{h}, \mathrm{P}<0.0001$ ), at Ser199 by 3.5 to 4 -fold (Fig. $8 \mathrm{~g}$ and i, $\mathrm{P}<0.0001$ ), and at Thr231 by 1.6 to 2 -fold (Fig. $8 \mathrm{~g}$ and $j, P=0.002)$. HIV infection had no significant effect on Tau phosphorylation at Thr205 (Fig. 8g and k).

\section{MVC reduced HIV-induced CNS tau phosphorylation}

Immunohistochemistry analysis showed that compared to infected (HIV group) animals, MVC treatment (HIV + MVC group) reduced pTau (Thr181) levels by 4.6-fold (Fig. 8a, c; $\mathrm{P}<0.0001, \mathrm{df}=14, \mathrm{~F}=5.94$ ). Western blot analysis confirmed these findings and showed that compared to animals in the HIV group, MVC treatment of infected animals reduced pTau (Thr181), pTau (Ser396), pTau (Ser199), and pTau (Thr231) levels respectively by 3 -fold (Fig. 8 e and $\mathrm{f}, P=0.011$ ); 17.8 -fold (Fig. $8 \mathrm{~g}$ and $\mathrm{h}, \mathrm{P}<0.0001$ ); 4.6-fold (Fig. $8 \mathrm{~g}$ and $\mathrm{i}, \mathrm{P}<$ 0.0001 ); and 1.5-fold (Fig. $8 \mathrm{~g}$ and $\mathrm{k}, P=0.048$ ). MVC treatment had no significant effect on pTau (Thr205) levels (Fig. $8 \mathrm{~g}$ and $\mathrm{k}$ ). Two-tailed t-tests were used for Fig. 8c.

\section{MVC reduced $A \beta$ retention and increased $A \beta$ release in human MDM}

$A \beta$ produced in the CNS are cleared through phagocytosis by cells of the monocyte lineage such as macrophages and microglia [46-49]. To determine whether HIV infection and/or CCR5 inhibitors may affect this process, we quantified the uptake, retention, and release of $\mathrm{A} \beta-42$ in HIV-infected and non-infected MDM, in the presence and absence of MVC. Compared to $A \beta$ levels in non-infected MDM $(526 \pm 10 \mathrm{pg} / \mathrm{ml}), \mathrm{HIV}-1$ infection increased macrophage $A \beta$ retention by 1.5 -fold $(796.5 \pm 15 \mathrm{pg} / \mathrm{ml})(P<0.0001$, Suppl Fig. 2a). MVC reduced $A \beta$ retention by 3.4 to 4.74 -fold in both infected 


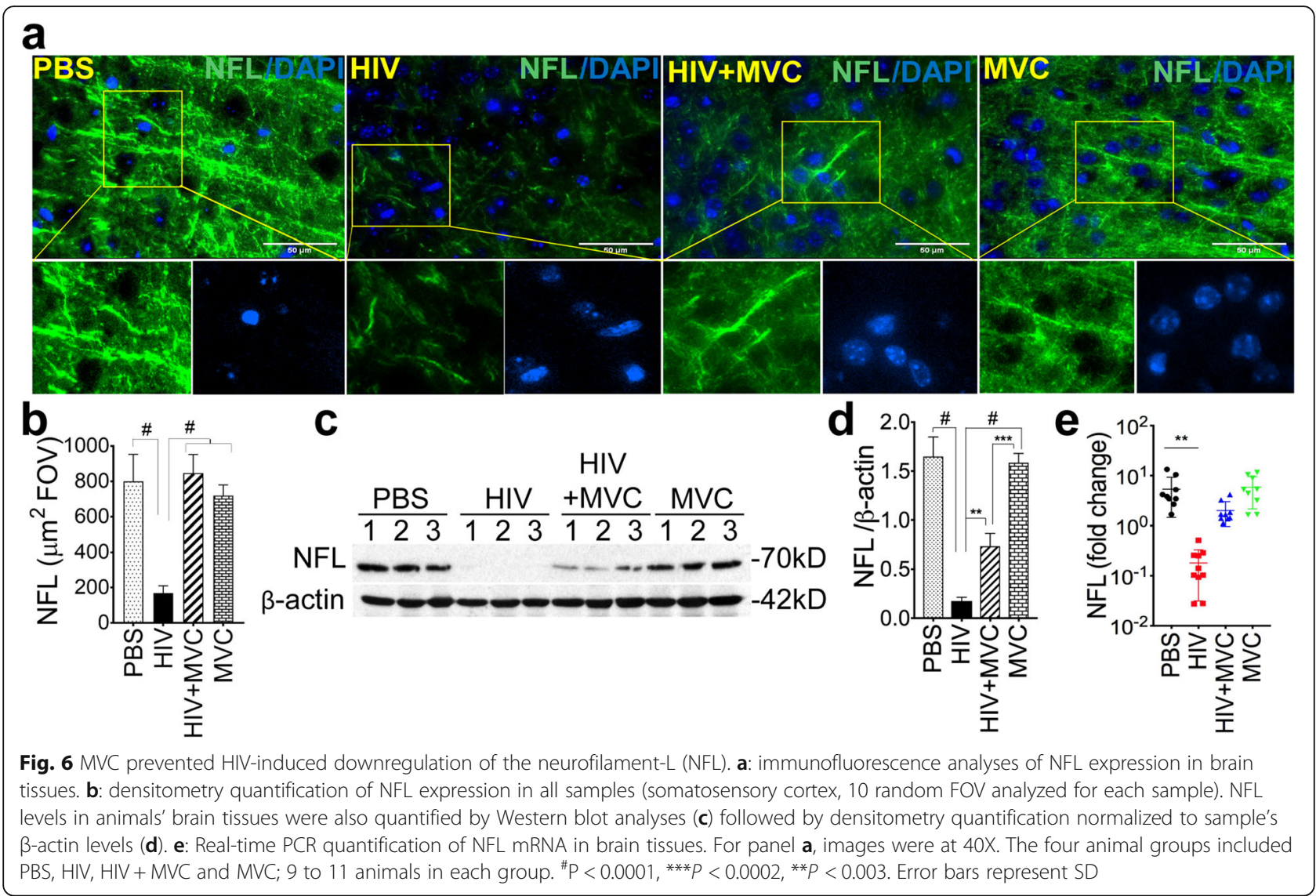

and non-infected MDM. A $\beta$ levels in non-infected and HIV-infected MDM exposed to MVC were 134 to 153 $\mathrm{pg} / \mathrm{ml}$ and 168 to $185 \mathrm{pg} / \mathrm{ml}$, respectively $(P<0.0001$, Suppl Fig. 2a).

Increased $A \beta$ retention in infected $(796.5 \pm 15 \mathrm{pg} / \mathrm{ml})$ and non-infected (526 $\pm 10 \mathrm{pg} / \mathrm{ml})$ MDM (Suppl Fig. 2a) correlated with minimal $\mathrm{A} \beta$ release in the culture media of infected $(83 \pm 19.6 \mathrm{pg} / \mathrm{ml})$ and non-infected $(116.6 \pm$ $12 \mathrm{pg} / \mathrm{ml}$ ) MDM (Suppl Fig. 2b). MVC increased A $\beta$ release from non-infected and HIV-infected MDM by 5fold and 4-fold, respectively ( $P<0.0001$, Suppl Fig. 2b). Levels of $\mathrm{A} \beta$ released in culture supernatants of MVCtreated non-infected and HIV-infected MDM were 575 to $608.6 \mathrm{pg} / \mathrm{ml}$ and 334 to $365 \mathrm{pg} / \mathrm{ml}$, respectively $(\mathrm{P}<$ 0.0001, Suppl Fig. 2b).

\section{MVC increased LRP1 and decreased RAGE expression in HBMEC}

Two major endothelial receptors regulate $A \beta$ transport across the BBB: RAGE, an influx receptor that binds and transport circulating plasma $\mathrm{A} \beta$ into the $\mathrm{CNS}$ [27-30]; and LRP1, an efflux-clearance receptor that binds and transport brain-derived $A \beta$ into the blood [31-33]. We confirmed the expression of RAGE and LRP1 in primary HBMEC (Suppl Fig. 3). Compared to controls [HBMEC treated with DMSO (vehicle)], exposure of HBMEC to A $\beta-42$ did not alter LRP1 or RAGE expression (Suppl Fig. 3a-c), but MVC treatment decreased RAGE expression by 2.1 -fold ( $P=0.0006$, Suppl Fig. $3 \mathrm{a}$ and $\mathrm{b})$ and increased LRP1 expression in HBMEC by 2.7 -fold $(P=$ 0.0002, Suppl Fig. 3a and c). In HBMEC exposed to A $\beta$ 42, MVC also increased LRP1 $(P=0.03$, Suppl Fig. 3a and c) and decreased RAGE expression (Suppl Fig. 3a and b) $(\mathrm{P}=0.04)$.

In the presence of MVC, LRP1 antagonist (but not RAGE antagonist) reduced endothelial $A \beta$ uptake and retention Quantification of $A \beta-42$ levels in trypsinized HBMEC (upper chamber of the transwell system) showed that in the absence of MVC, both LRP1 and RAGE inhibitors reduced endothelial $A \beta$ uptake and retention by 2 to 2.3-fold (Suppl Fig. 3d). Compared to A $\beta$ levels in control HBMEC $(185.5 \pm 20 \mathrm{pg} / \mathrm{ml}), \mathrm{A} \beta$ levels in HBMEC treated with LRP1 and RAGE inhibitors were $79.6 \pm 12$ $\mathrm{pg} / \mathrm{ml}$ and $84.2 \pm 0.8 \mathrm{pg} / \mathrm{ml}$, respectively $(\mathrm{P}=0.0002$, Suppl Fig. 3d). MVC alone had no significant effect on endothelial $A \beta$ uptake $[A \beta$ levels in MVC-treated HBMEC were 214.3 to $238 \pm 28 \mathrm{pg} / \mathrm{ml}$ compared to $185.5 \pm 20 \mathrm{pg} / \mathrm{ml}$ in non-MVC treated cells (Suppl Fig. 3d)]. In MVC-treated cells, RAGE inhibitors did not 


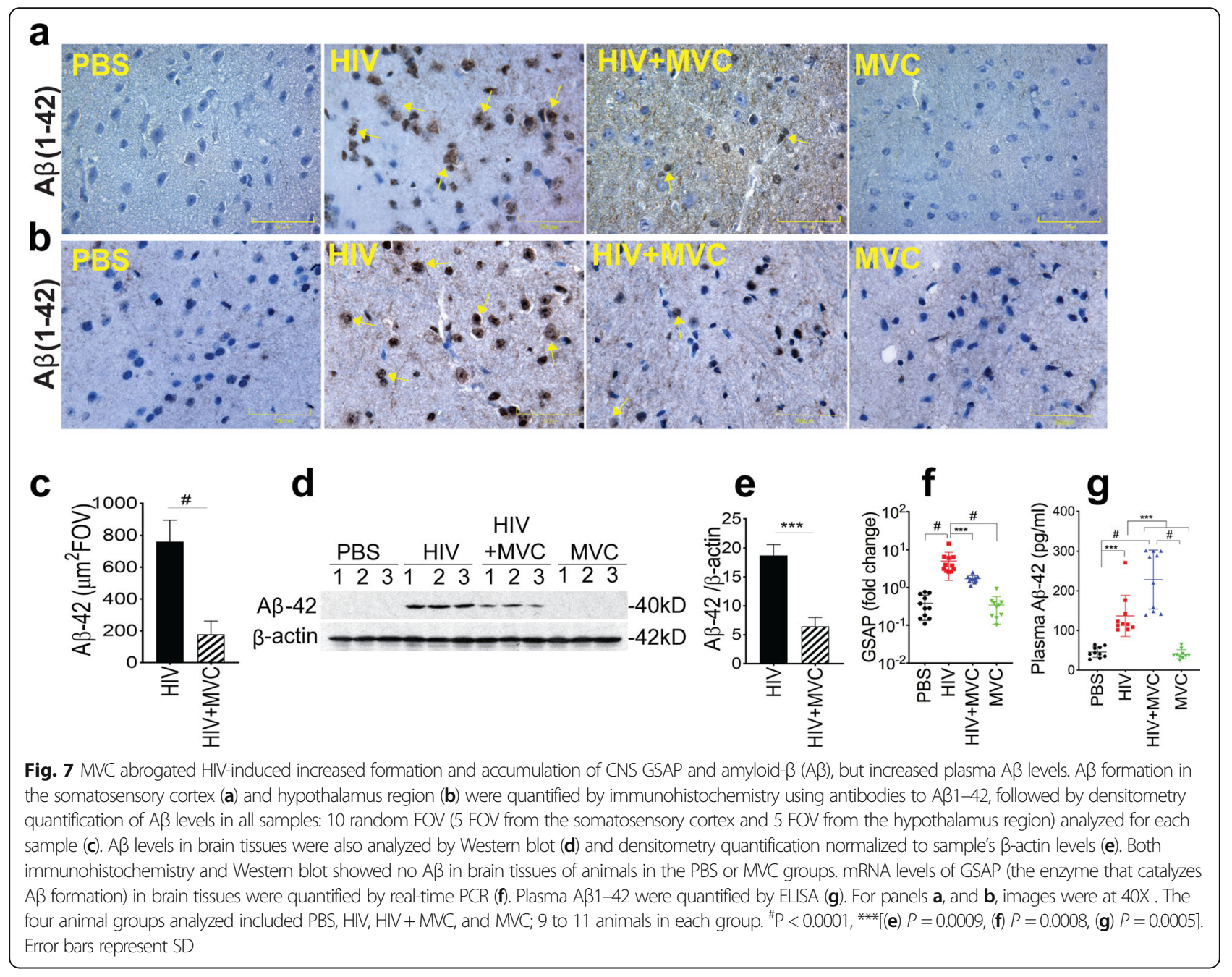

alter $A \beta$ uptake and retention $[A \beta$ levels in HBMEC treated with both MVC and RAGE inhibitors were 202 to $271.6 \pm 25 \mathrm{pg} / \mathrm{ml}$ ], but LRP1 inhibitors reduced $A \beta$ uptake and retention 2 to 2.6-fold [A $\beta$ levels in HBMEC treated with both MVC and LRP1 inhibitors were 82 to $139 \pm 2.5 \mathrm{pg} / \mathrm{ml}, \mathrm{P}<0.0001$, Suppl Fig. 3d]

\section{MVC increased transendothelial A $\beta$ transport and LRP1 antagonist (but not RAGE antagonist) blocked MVC- induced transendothelial $A \beta$ transport}

Quantification of A $\beta-42$ levels in the lower chamber culture media ( $A \beta$ transported from the upper to the lower chamber of the transwell) showed that in the absence of MVC, both LRP1 and RAGE inhibitors reduced endothelial $\mathrm{A} \beta$ transport by 1.3 to 1.7 -fold (Suppl Fig. 3e). Compared to $A \beta$ levels in the lower chamber media of control HBMEC $(105.4 \pm 6.6 \mathrm{pg} / \mathrm{ml}), \mathrm{A} \beta$ levels in lower chamber media of cells treated with LRP1 and RAGE inhibitors were respectively $59.8 \pm 5.1 \mathrm{pg} / \mathrm{ml} \quad(\mathrm{P}<0.0001$, Suppl Fig. 3e) and $79 \pm 11.3 \mathrm{pg} / \mathrm{ml}(P=0.003$, Suppl Fig. 3e). MVC increased $A \beta$ transport across in vitro BBB model by 3.2 to 3.4 -fold ( $\mathrm{P}<0.0001$, Suppl Fig. 3e). Compared to $\mathrm{A} \beta$ levels in control HBMEC lower chamber media $(105.4 \pm 6.6 \mathrm{pg} / \mathrm{ml}), \mathrm{A} \beta-42$ levels in the lower chamber media of MVC-treated HBMEC were 341 to $359 \pm 4 \mathrm{pg} /$ $\mathrm{ml}(\mathrm{P}<0.0001$, Suppl Fig. 3e)]. In the presence of MVC, the RAGE inhibitor had no effect on $M V C$-induced $A \beta$ transendothelial transport $[A \beta$ levels in the lower chamber media of HBMEC treated with both MVC and RAGE inhibitor were 322 to $325.5 \mathrm{pg} / \mathrm{ml}$, compared to 341 to 359 $\mathrm{pg} / \mathrm{ml}$ in MVC-treated HBMEC]. The LRP1 inhibitor reduced $M V C$-induced $A \beta$ transendothelial transport by 4 to 6.24-fold [A $\beta$ levels in the lower chamber media of HBMEC treated with both MVC and LRP1 inhibitor were 54.6 to $63 \pm 3 \mathrm{pg} / \mathrm{ml}$, compared to 341 to $359 \mathrm{pg} / \mathrm{ml}$ in MVC-treated HBMEC, $\mathrm{P}<0.0001$, Suppl Fig. 3e].

\section{Discussion}

There is evidence of AD-like pathologies in HIV-infected individuals, including increased production of neurotoxic $\mathrm{A} \beta$, Tau hyperphosphorylation, formation of amyloid plaques and NFTs-like structures in the CNS [17-20]. We 


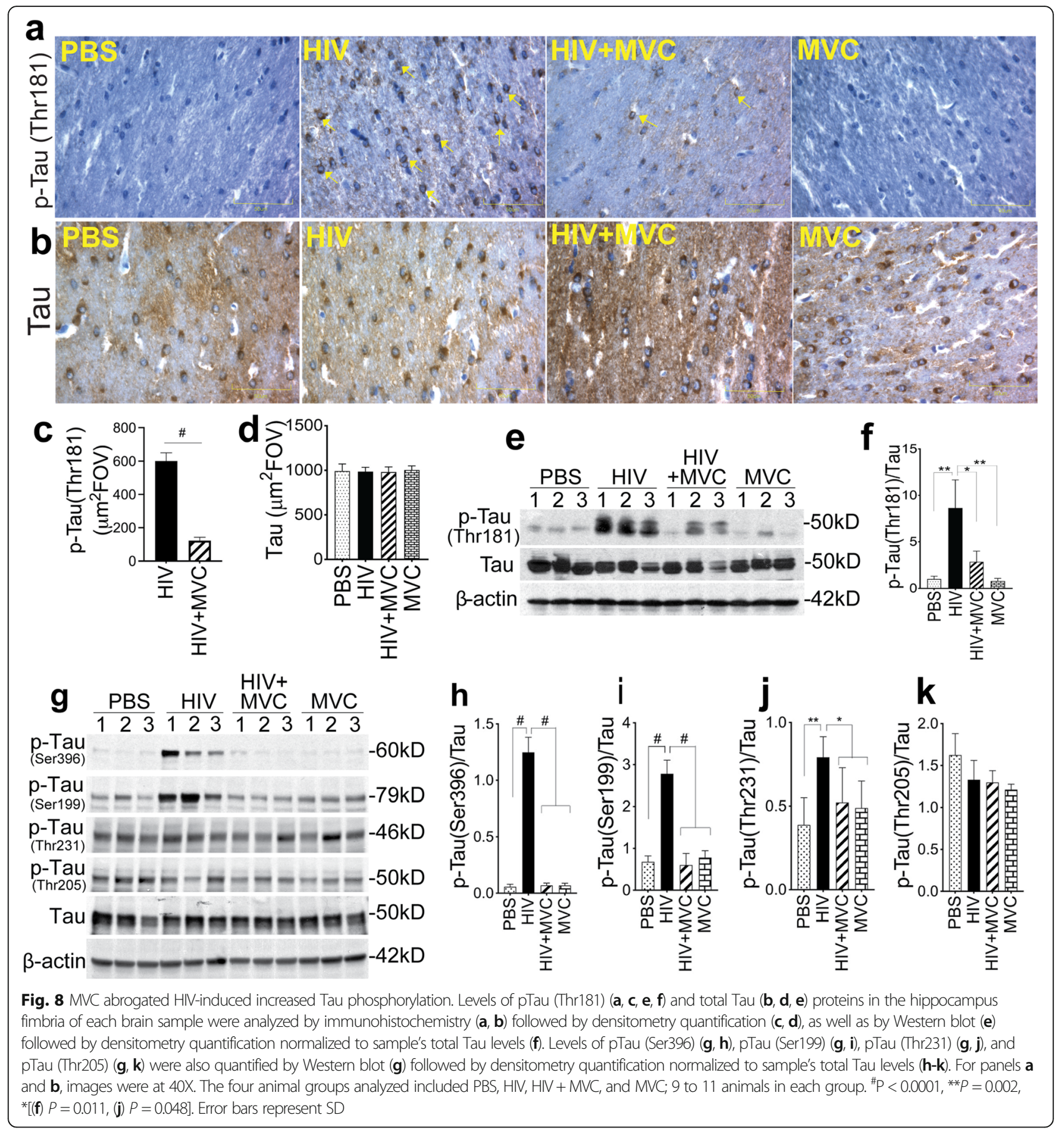

have reproduced these findings in hu-PBL-NSG mice, a well-characterized and validated animal model that mimics HIV/AIDS clinical conditions [50-56]. We demonstrate that HIV-1 infection significantly increased CNS A $\beta-42$ and phosphorylation of Tau at Thr181, Ser396, Ser199, and Thr231 in these animals. Brain tissues from patients with $\mathrm{AD}$ and other dementia also showed increased accumulation of pTau in neurons, glial cells, and NFTs, including Tau hyperphosphorylation at Thr181,
Thr231, Ser396, and Ser199 [57-60]. In AD mice models, brain damage is associated with increased pTau (Ser199) in the cerebral cortex and hippocampus, and reduced autophagy [61]. Our results suggest that HIV and/or viralinduced factors are directly involved in the development of AD-like pathologies in HIV-infected individuals, which agrees with previous findings. In fact, in vitro, ex vivo, and in vivo studies showed that HIV and viral proteins induced the production and aggregation of the toxic forms 
of $A \beta$ ( $A \beta-40$ and $A \beta-42)$, the formation of amyloid plaques, and Tau hyperphosphorylation [62-68], and that $A \beta$ peptides can further enhance HIV replication [69]. The direct role of HIV in the development of amyloidogenesis and pTau pathology is further supported by autopsy studies showing that the presence of $A \beta$ deposits and $p T a u$ pathology in brain tissues of HIV-infected humans are often associated with high viral loads and neurocognitive impairments, including impairments in speed of information processing, attention, and working memory [21, 22]; and impairment in prospective memory [70, 71]. Studies of HIV-1 transgenic rats also showed marked increase in pTau (Thr181, Thr231, and Ser396) in the hippocampus [66]; and HIV-1 matrix protein p17 injected into mouse hippocampus co-localizes with pTau fibrils and amyloid plaques to further increase $A \beta$ expression and induce neurocognitive impairment [67].

The current study is, to our knowledge, the first to show that HIV-induced $A \beta$ and pTau is associated with transcriptional upregulation of GSAP, an enzyme that modulates $A \beta$ formation [23]. In $A D$ amyloidogenic pathway, the APP is sequentially cleaved by $\beta$ and $\gamma$ secretases to generate neurotoxic $A \beta$ fragments that oligomerize, form amyloid fibrils, and aggregate into amyloid plaques [72-74]. GSAP selectively and specifically regulates $\gamma$-secretase interaction with APP to increase $A \beta$ production [23-26], and has been associated with $\mathrm{AD}$ and disease progression. Compared to agematched controls, GSAP levels are significantly higher in brain tissues of AD patients [75-77], patients with other neurodegenerative diseases such as Down syndrome [78], and in AD mice models [75, 77, 79]. Silencing GSAP expression significantly reduced cellular $\gamma$ secretase activity and $A \beta$ production in vitro $[23,80,81]$; reduced CNS A $\beta$ levels, amyloid plaque formation and pTau in AD mouse models, without altering other $\gamma$ secretase function such as Notch-dependent pathways $[23,75,77,79-81]$.

Although it is well established that increased CNS and cerebrospinal fluid (CSF) $A \beta-42$ is a hallmark of $A D$ pathology, there have been contradictory findings on the role of plasma $A \beta-42$ in $A D$ and associated brain pathologies. Amyloidogenesis, pTau pathology, cognitive decline and $\mathrm{AD}$ have been associated with low/decreasing plasma $A \beta-42$ [82-87] and increased plasma $A \beta-42$ levels [88-98], whereas other studies found no significant difference in plasma $\mathrm{A} \beta$ of $\mathrm{AD}$ patients and agematched controls [99-102], and no association between plasma and brain or CSF A $\beta$ levels [101, 103, 104]. In our current study, HIV infection increased plasma $A \beta-$ 42 by 3 -fold, compared to control groups. There have been reports of lower serum $A \beta-42$ in people living with HIV (PLWH) compared to gender and age matched seronegative controls [105], but HIV-infected subjects with HAND were more likely to have higher plasma $A \beta$ 42 compared to healthy controls and PLWH without HAND [106]. This suggests that our findings of higher plasma $A \beta-42$ in the HIV group may be associated with higher $\mathrm{CNS}$ impairment. However, plasma and brain $\mathrm{A} \beta$ levels don't always correlate because blood $A \beta$ is also derived from non-CNS cells and has increased propensity to bind to other plasma proteins such as albumin, lipoproteins, and complement factors [107-110].

HIV Tat interacts with APP in vitro and in vivo to increase A $\beta-42$ levels and amyloid plaques [111]. Considering the direct role of HIV and viral protein in $A \beta-42$ production and Tau hyperphosphorylation, it would be expected that reduced viral load with ART would be associated with reduced CNS A $\beta-42$ and pTau; however, autopsy studies showed increased amyloidogenesis and pTau pathology in HIV-infected individuals who had been on long-term ART [19-21]. It is not known whether this is associated with specific ART regimens. Some studies showed that saquinavir and atazanavir significantly increased APP, $\beta$-secretase- $1, A \beta-40$, and $A \beta$ 42 in neuronal cultures and in simian immunodeficiency virus (SIV)-infected macaques [112], and inhibited macrophages $A \beta$ phagocytosis [113]. Other studies showed that lopinavir, nelfinavir, ritonavir, and saquinavir decreased $A \beta, \beta$-secretase- 1 and $\gamma$-secretase activities in neuronal cultures but had no effect on $A \beta$ production in APP transgenic mice [113]. The effect of CCR5 inhibitors on HIV-associated amyloidogenesis and pTau have not been investigated.

CCR5 is a major HIV co-receptor [114, 115], is expressed in many cell types [2], and the CCR5 antagonist MVC is currently used for the treatment of subjects infected with CCR5-tropic HIV [9, 10]. In our current study, MVC decreased viral loads in the blood and brain tissues and blocked HIV-induced immunosuppression. Most importantly, MVC significantly reduced HIVinduced CNS A $\beta$ production and Tau phosphorylation, and significantly decreased HIV-induced transcriptional upregulation of GSAP, an endoprotease that catalyzes APP cleavage and A $\beta$ formation [23]. Previous studies also showed that CCR5 was involved in neuroinflammation and cellular chemotaxis in both HAND [116-118] and AD [119-121]. CCR5 is involved in glial injury, immune dysregulation, and microglia activation in Parkinson's disease [122] and AD [119]. MVC monotherapy reduced CNS viral loads and inflammation in SIVinfected macaques, decreased the activation of CNS leukocytes, and reduced axonal APP levels [123].

The protective effects of MVC on brain cells could be associated with its ability to cross the $\mathrm{BBB}$ and enter the CNS. CSF studies suggest that MVC has a high CNS penetration effectiveness score [124], with MVC levels in human CSF above the protein-adjusted inhibitory 
concentration (IC90) of $0.57 \mathrm{ng} / \mathrm{ml}$ [125-127]. These data would suggest that MVC readily enters the CNS. Our current study in hu-PBL-NSG mice using human equivalent doses and similar treatment schedules as in human studies showed high levels of MVC in brain tissues at 3 weeks of treatment $(81-685 \mathrm{ng} / \mathrm{g})$, and a positive correlation between plasma and brain MVC levels. The fact that there was no difference in the weight of MVC-treated and untreated animals shows that MVC did not cause overt toxicities in these animals.

Remarkably, although animals in the $\mathrm{HIV}+\mathrm{MVC}$ group showed significantly reduced CNS $A \beta-42$ levels, they had higher plasma $A \beta-42$ levels (1.67-fold higher than in the HIV group and 5.7-fold higher than in the MVC group). These results suggest that in the context of HIV infection, MVC increase the transport of $A \beta-42$ from the brain into the peripheral blood. This hypothesis is further supported by our data showing that MVC decrease RAGE while significantly increasing LRP1 expression in BBB cells. RAGE, an influx transporter largely expressed at the $\mathrm{BBB}$, binds soluble $\mathrm{A} \beta$ and mediate its transendothelial transport from the blood into the CNS [27-30]. Compared to age-matched controls, brain tissues from $A D$ patients and $A D$ animal models showed significantly higher expression of RAGE in the brain endothelium, neurons, and microglia [30, 128-130], with the highest RAGE levels correlating with higher burden of amyloid plaques and NFTs [128], impairment in learning and memory $[29,131]$. LRP1, an efflux receptor expressed in BBB cells, binds, and mediates $A \beta$ transendothelial transport from the brain into the peripheral blood [31-33]. Thus, LRP1 function as a CNS A $\beta$ clearance receptor and our data showing that MVC decrease RAGE and increase LRP1 in HBMEC, increase transendothelial $\mathrm{A} \beta$ transport, and that LRP1 antagonist (but not RAGE antagonist) blocked MVC-induced transendothelial $A \beta$ transport, suggest that MVC treatment can induce/increase CNS A $\beta$ clearance via LRP1 pathways. Our supplemental data also showed that HIV infection increased $A \beta$ uptake and retention and reduce $A \beta$ release in human MDM, whereas MVC reduced $A \beta$ retention while increasing $A \beta$ release from MDM. This MVC-mediated A $\beta$ efflux from both leukocytes and the CNS may have contributed to the increased plasma $A \beta$ levels in infected MVC-treated animals.

Our data showing protective effects of MVC against HIV-induced CNS A $\beta$ production and Tau phosphorylation suggest that an ART regimen containing CCR5 antagonists such as MVC could reduce the likelihood of HIV-induced amyloidogenesis and pTau pathology in infected individuals. This would likely be associated with improved cognition, as there is evidence that MVCcontaining ART reduced leukocytes activation, reduced TNF- $\alpha$, and improved neurocognitive function in some
PLWH [132-135]. However, other studies of MVC effects on the CNS have reported conflicting results, with one clinical trial showing no effect of MVC-based ART on neuropsychological performance [136]; whereas another clinical trial showed that MVC-based ART marginally improved neurocognitive function but significantly improved performance in executive function [137]. The wide variations in antiretroviral drugs used in treatment regimens in these different studies likely played a role in the discrepancies observed.

Our current data also showed that HIV-induced $A \beta$ and pTau was associated with increased neuronal injury, as evidenced by decreased expression of markers of axonal filaments (NFL), neuronal microtubules (MAP 2), and markers of neuronal development and differentiation (NeuN). This confirms previous evidence from in vitro, in vivo, and ex vivo studies showing that neuronal injury and neurodegeneration are neuropathological features of HAND [15, 138, 139] and AD [140-142]. Significantly, we demonstrated that MVC preserved neuronal structure and integrity and reduced HIV-induced downregulation of NFL, MAP 2, and NeuN. MVC also decreased HIV Tat- and V3-induced neurotoxicity [118, 143], attenuated Tat-induced neuroinflammation [118], and increased $\mathrm{N}$-acetyl aspartate/creatine ratios, a marker of neuronal integrity, in PLWH [144]. MVC treatment also improved neural repair following stroke and traumatic brain injury [145]. These studies show a broad therapeutic potential of CCR5 antagonists in preventing neuronal injury and abrogating neuropathology in several CNS diseases, including HIV/AIDS.

The BBB is a complex and dynamic structure that acts as a biological interface between the blood and the brain and plays a critical role in maintaining CNS homeostasis $[146,147]$. Our current data showed that in addition to increasing $A \beta$ production and pTau, HIV infection of animals resulted in increased BBB alterations, as evidenced by decreased expression of the brain endothelial $\mathrm{TJ}$ proteins claudin-5, ZO-1, and ZO-2, all markers of BBB integrity. Claudin-5 is a transmembrane protein [148] whereas ZO-1 and ZO-2 are intracellular adaptor proteins [149]. Although TJ proteins such as occludin [150-152], ZO-1 [151-155], and ZO-2 [152, 154] have been detected in other cells of the neurovascular unit such as pericytes [152], astrocytes [151, 153, 154], neurons [150] and oligodendrocytes [155], these TJ proteins are primarily expressed in brain endothelial cells, the major BBB component, where they provide intercellular seals and increase paracellular tightness [156-158]. The structure and functional integrity of $\mathrm{TJ}$ proteins impact cellular adhesion and regulate actin cytoskeletal rearrangement and transmigration of blood leukocytes into the CNS [146, 147]. In our studies, these $\mathrm{TJ}$ proteins were mostly expressed on cerebral blood vessels. Our current findings are in agreement 
with previous studies, including human post-mortem studies, showing that both HIV and viral proteins directly induce BBB injury [11, 12, 14, 159]; and that both HAND $[12,14,160]$ and $\operatorname{AD}[159,161,162]$ are associated with increased BBB injury as well as impairment in BBB tightness and function.

In addition to HIV and viral proteins directly causing $\mathrm{BBB}$ alterations, $\mathrm{A} \beta$ produced following HIV infection can further increase endothelial injury and $\mathrm{BBB}$ dysfunction. In fact, exposure of $B B B$ cells to $A \beta$ results in decreased expression of $\mathrm{TJ}$ proteins and increased $\mathrm{BBB}$ permeability $[161,163,164]$. CCR5 is also involved in this process; exposure of human brain endothelial cells to $A \beta-42$ or $A \beta$ 40 induced a dose-dependent increase in CCR 5 expression, chemotaxis, and monocytes transmigration through the BBB $[120,121,165]$. In this study, HIV-induced BBB alterations were associated with increased infiltration of leukocytes into the brain and significantly, we demonstrated that MVC protected the BBB and prevented HIVinduced leukocytes infiltration into the CNS. These results confirm previous in vitro findings showing that MVC and CCR5 neutralizing antibodies protect against HIV-, gp120- and Tat-induced endothelial inflammation and BBB alterations $[2,9,37,166]$.

\section{Conclusions}

The current study is, to our knowledge, the first to demonstrate that HIV-induced $\mathrm{A} \beta$ and pTau is associated with transcriptional upregulation of GSAP, an endoprotease that catalyzes $\gamma$-secretase cleavage of APP and A $\beta$ formation [23-26], that CCR5 is involved in HIVinduced $A \beta$ production and Tau hyperphosphorylation in the CNS; and that the CCR5 antagonist MVC significantly reduced HIV-induced $A \beta$ and pTau pathology, abrogates HIV-induced upregulation of GSAP, decreased RAGE and increased LRP1 expression in HBMEC, and induced/increased the transendothelial transport of $A B$ via LRP1 pathways. We further demonstrate that MVC reduced HIV-induced $A \beta$ uptake and retention while increasing $A \beta$ release from MDM, increased plasma $A \beta$, reduced HIV-induced neuronal damage and BBB alterations in vivo. These results are significant and suggest that therapeutically targeting CCR5 can reduce or abrogate HIV-induced AD-like CNS pathologies. These findings have translational significance, as ART regimens containing MVC could reduce the risk of $A \beta$ production and Tau hyperphosphorylation in the brain, increase CNS $A \beta$ efflux, reduce brain amyloid burden, reduce HIV-induced neuronal damage and BBB alterations, and reduce the risk of $\mathrm{AD}$-like $\mathrm{CNS}$ pathologies in infected individuals.

\section{Abbreviations}

HIV-1: Human immunodeficiency virus type-1; PLWH: people living with HIV; CCR5: C-C chemokine receptor type-5; CXCR4: C-X-C chemokine receptor type-4; MVC: Maraviroc; AD: Alzheimer's Disease; HAND: HIV-associated neurocognitive disorders; CNS: central nervous system; NSG: NOD/scid-IL$2 R \gamma_{c}{ }^{\text {null. }}$ PBL: peripheral blood lymphocytes; hu (or h): human; $A \beta$ : amyloidbeta; pTau: phospho-Tau; APP: Amyloid precursor protein; GSAP: gammasecretase activating protein; ZO-1: Zonula occludens-1; ZO-2: Zonula occludens-2; BBB: blood-brain barrier; TJ: tight junctions; ART: antiretroviral therapy; UNMC: University of Nebraska Medical Center; NIH: National Institute of Health; FACS: fluorescence activated cell sorting; PBS: phosphate-buffered saline; PBST: PBS containing 0.1\% Tween-20; OCT: optimal cutting temperature; qPCR: quantitative polymerase chain reaction; DMSO: dimethyl sulfoxide; EDTA: ethylenediaminetetraacetic acid; ELISA: enzyme-linked immunosorbent assay; HLA: human leukocyte antigen; MAP 2: microtubuleassociated protein-2; NeuN: neuronal nuclei; NFL: neurofilament-L; RT: room temperature; min: minutes; s: seconds; HRP: horseradish peroxidase; DAB: 3,3'-diaminobenzidine; DAPI: 4',6-diamidino-2-phenylindole; FOV: fieldsof-view; UPLC-MS/MS: Ultraperformance liquid chromatography-tandem mass spectrometry; IS: internal standard; RNA: ribonucleic acid;

cDNA: complementary deoxyribonucleic acid; dNTP: deoxynucleoside triphosphates; LTR: long terminal repeats; pol: polymerase; Tat: transactivator of transcription; gag: group-specific antigen; GAPDH: glyceraldehyde 3phosphate dehydrogenase; SD: standard deviation; g: grams; ng: nanograms; ml: milliliter; $\mu$ l: microliter; $\mu \mathrm{M}$ : micromolar; nM: nanomolar; inh: inhibitor; MDM: monocyte-derived macrophage; HBMEC: Human brain microvascular endothelial cells; DMEM: Dulbecco's Modified Eagle's Medium; APP: amyloid precursor protein; RAGE: receptor for advanced glycation end products; LRP1: low-density lipoprotein receptor-related protein-1

\section{Supplementary Information}

The online version contains supplementary material available at https://doi. org/10.1186/s13024-021-00500-0.

Additional file 1: Supplemental Fig. 1. Lower magnification (4x) images show the mice brain regions analyzed. a: somatosensory cortex (CTX); b: hippocampus fimbria (Fba); MG: meningeal areas

Additional file 2: Supplemental Fig. 2. MVC abrogated HIV-induced increased $A \beta$ retention and increase $A \beta$ release in human MDM. MDM infection and $A \beta$ treatment were performed as detailed in the Methods section. Levels of $A \beta$ in trypsinized MDM lysates (a) and $A \beta$ in MDM culture supernatant $(\mathbf{b})$ were quantified by ELISA. Each treatment condition was performed in duplicate. ${ }^{\#} P<0.0001,{ }^{* * *} P=0.0002$. Error bars represent SD

Additional file 3: Supplemental Fig. 3. MVC reduced RAGE and increased LRP1 expression in primary HBMEC, and increased transendothelial $A \beta$ transport. $\operatorname{RAGE}(\mathbf{a}, \mathbf{b})$ and LRP1 $(\mathbf{a}, \mathbf{c})$ levels in primary HBMEC were analyzed by Western blot (a) followed by densitometry quantification normalized to each sample's $\beta$-actin levels (b, c). Levels of A $\beta$ in trypsinized HBMEC lysates (upper chamber of the transwell) (d) and in the lower chamber culture media (e) were quantified by ELISA. Each treatment condition was performed in duplicate. ${ }^{\#} P<$ 0.0001 , ${ }^{* *}[(\mathbf{b}) P=0.0006,(\mathbf{c}) P=0.0004,(\mathbf{d}) P=0.0003] ;{ }^{* *}[(\mathbf{b}) P=0.0015$, (e) $P=0.003)]$; ${ }^{*}[(\mathbf{b}) P=0.04$, (c) $P=0.03]$. For panel d ${ }^{*} P=0.048 \mathrm{com}-$ pared to A $\beta$-exposed HBMEC not treated with MVC. "Vehicle" represents DMSO only treatment; inh: inhibitor. Error bars represent SD

Additional file 4. Original blots.

Additional file 5. Animals' weight.

\section{Acknowledgments}

We thank the NIH AIDS Research and Reference Reagent Program for providing ACH-2 cells, the UNMC Flow Cytometry Research Facility for assistance with FACS analyses, Ms. Hong Li and Dr. James Hilaire for technical assistance, thank Mr. Doug Meigs and Mr. Jeffrey Patterson for critical reading of the manuscript.

\section{Authors' contributions}

B.B. carried out specimen processing, histology, immunoassays, RNAscope, qPCR, Western blot, in vitro experiments, participated in the making of Figures, data analysis and writing the methods and results. S.M.W. carried out NSG mice infection, MVC treatment, regular monitoring of animals' weight, 
specimen collection and processing, and FACS analyses. J.M. carried UPLCMS/MS drug quantification. G.D.K. conceived and designed the study, carried out NSG mice infection, MVC treatment, specimen collection, data analysis, participated in the making of Figures and wrote the manuscript. All authors read and approved the final manuscript.

\section{Funding}

This work was supported by grant from the NIH, NIMH R01 MH094160 and 1R21 MH123303 (to GDK).

\section{Availability of data and materials}

All data generated or analyzed during this study are included in this publication and/or are available from the corresponding author on reasonable request.

\section{Declarations}

\section{Ethics (IACUC) approval and consent to participate}

This study was performed under a protocol approved by the UNMC Institutional Animal Care and Use Committee (IACUC Protocol number 08008-FC.

\section{Consent for publication}

Not applicable.

\section{Competing interests}

The authors declare that they have no competing interests.

\section{Author details}

'Department of Pharmacology and Experimental Neuroscience, College of Medicine, University of Nebraska Medical Center, 985800 Nebraska Medical Center, Omaha, NE 68198-5800, USA. ${ }^{2}$ Huvepharma, 421 W Industrial Lake Drive, Lincoln, NE 68528, USA.

Received: 19 March 2021 Accepted: 3 November 2021

Published online: 22 November 2021

\section{References}

1. Wilen CB, Tilton JC, Doms RW. Molecular mechanisms of HIV entry. Adv Exp Med Biol. 2012;726:223-42

2. Kanmogne GD, Schall K, Leibhart J, Knipe B, Gendelman HE, Persidsky Y HIV-1 gp120 compromises blood-brain barrier integrity and enhances monocyte migration across blood-brain barrier: implication for viral neuropathogenesis. J Cereb Blood Flow Metab. 2007:27:123-34.

3. Lee B, Ratajczak J, Doms RW, Gewirtz AM, Ratajczak MZ. Coreceptor/ chemokine receptor expression on human hematopoietic cells: biological implications for human immunodeficiency virus-type 1 infection. Blood. 1999;93:1145-56.

4. Naif HM. Pathogenesis of HIV infection. Infect Dis Rep. 2013;5:e6

5. Huang Y, Paxton WA, Wolinsky SM, Neumann AU, Zhang L, He T, et al. The role of a mutant CCR5 allele in HIV-1 transmission and disease progression. Nat Med. 1996;2:1240-3.

6. Samson M, Libert F, Doranz BJ, Rucker J, Liesnard C, Farber CM, et al. Resistance to HIV-1 infection in caucasian individuals bearing mutant alleles of the CCR-5 chemokine receptor gene. Nature. 1996:382:722-5.

7. Reuter S, Braken P, Jensen B, Sierra-Aragon S, Oette $M$, Balduin $M$, et al. Maraviroc in treatment-experienced patients with HIV-1 infection experience from routine clinical practice. Eur J Med Res. 2010;15:231-7.

8. Babiker ZO, Douthwaite ST, Collier LE, Pennell A, Uriel AJ, Wilkins E. Real-life outcomes of maraviroc-based regimens in HIV-1-infected individuals. J Int Assoc Providers AIDS Care. 2013:12:12-4.

9. Woollard SM, Kanmogne GD. Maraviroc: a review of its use in HIV infection and beyond. Drug Des Devel Ther. 2015;9:5447-68.

10. AIDSinfo: FDA-Approved HIV Medicines. US-DHHS.; 2020. https://www.a idsinfonihgov/understanding-hiv-aids/fact-sheets/21/58/fda-approved-hivmedicines.

11. Berger JR, Avison M. The blood brain barrier in HIV infection. Front Biosci. 2004:9:2680-5

12. Persidsky Y, Ramirez SH, Haorah J, Kanmogne GD. Blood-brain barrier: structural components and function under physiologic and pathologic conditions. J Neurolmmune Pharmacol. 2006;1:223-36.
13. Zayyad Z, Spudich S. Neuropathogenesis of HIV: from initial neuroinvasion to HIV-associated neurocognitive disorder (HAND). Current HIV/AIDS Rep. 2015;12(1):16-24. https://doi.org/10.1007/s11904-014-0255-3.

14. Rao VR, Ruiz AP, Prasad VR. Viral and cellular factors underlying neuropathogenesis in HIV associated neurocognitive disorders (HAND). AIDS Res Ther. 2014;11:13.

15. Saylor D, Dickens AM, Sacktor N, Haughey N, Slusher B, Pletnikov M, et al. HIV-associated neurocognitive disorder--pathogenesis and prospects for treatment. Nat Rev Neurol. 2016;12:234-48.

16. Heaton RK, Clifford DB, Franklin DR Jr, Woods SP, Ake C, Vaida F, et al. HIVassociated neurocognitive disorders persist in the era of potent antiretroviral therapy: CHARTER study. Neurology. 2010;75:2087-96.

17. Giometto B, An SF, Groves M, Scaravilli T, Geddes JF, Miller R, et al. Scaravilli F: Accumulation of $\beta$-amyloid precursor protein in HIV encephalitis: Relationship with neuropsychological abnormalities. Ann Neurol. 1997;42: 34-40.

18. Esiri MM, Biddolph SC, Morris CS. Prevalence of Alzheimer plaques in AIDS. J Neurol Neurosurg Psychiatry. 1998;65:29-33

19. Green DA, Masliah E, Vinters HV, Beizai P, Moore DJ, Achim CL. Brain deposition of beta-amyloid is a common pathologic feature in HIV positive patients. Aids. 2005;19:407-11.

20. Achim CL, Adame A, Dumaop W, Everall IP, Masliah E. Increased accumulation of intraneuronal amyloid beta in HIV-infected patients. J Neurolmmune Pharmacol. 2009:4:190-9.

21. Soontornniyomkij V, Moore DJ, Gouaux B, Soontornniyomkij B, Sinsheimer JS, Levine AJ. Associations of regional amyloid-beta plaque and phosphotau pathology with biological factors and neuropsychological functioning among HIV-infected adults. J Neurovirol. 2019;25:741-53.

22. Brew BJ, Crowe SM, Landay A, Cysique LA, Guillemin G. Neurodegeneration and ageing in the HAART era. J Neurolmmune Pharmacol. 2009:4:163-74.

23. He G, Luo W, Li P, Remmers C, Netzer WJ, Hendrick J, et al. Gammasecretase activating protein is a therapeutic target for Alzheimer's disease. Nature. 2010;467:95-8

24. Netzer WJ, Dou F, Cai D, Veach D, Jean S, Li Y, et al. Gleevec inhibits betaamyloid production but not notch cleavage. Proc Natl Acad Sci U S A. 2003, 100:12444-9.

25. Zhu M, Tao Y, He Q, Gao H, Song F, Sun YM, et al. Common GSAP promote variant contributes to Alzheimer's disease liability. Neurobiol Aging. 2014;35: 2656 e2651-7.

26. Xu P, Chang JC, Zhou X, Wang W, Bamkole M, Wong E, et al. GSAP regulates lipid homeostasis and mitochondrial function associated with Alzheimer's disease. J Exp Med. 2021;218.

27. Mackic JB, Stins M, McComb JG, Calero M, Ghiso J, Kim KS, et al. Human bloodbrain barrier receptors for Alzheimer's amyloid-beta 1-40. Asymmetrical binding, endocytosis, and transcytosis at the apical side of brain microvascular endothelial cell monolayer. J Clin Invest. 1998;102:734-43.

28. Deane R, Du Yan S, Submamaryan RK, LaRue B, Jovanovic S, Hogg E, et al. RAGE mediates amyloid-beta peptide transport across the blood-brain barrier and accumulation in brain. Nat Med. 2003:9:907-13.

29. Fang F, Lue LF, Yan S, Xu H, Luddy JS, Chen D, et al. RAGE-dependent signaling in microglia contributes to neuroinflammation, Abeta accumulation, and impaired learning/memory in a mouse model of Alzheimer's disease. FASEB J Off Publ Fed Am Soc Exp Biol. 2010:24:1043-55.

30. Fang F, Yu Q, Arancio O, Chen D, Gore SS, Yan SS, et al. RAGE mediates Abeta accumulation in a mouse model of Alzheimer's disease via modulation of beta- and gamma-secretase activity. Hum Mol Genet. 2018; 27:1002-14

31. Shibata M, Yamada S, Kumar SR, Calero M, Bading J, Frangione B, et al. Clearance of Alzheimer's amyloid-ss (1-40) peptide from brain by LDL receptor-related protein-1 at the blood-brain barrier. J Clin Invest. 2000;106: 1489-99.

32. Deane R, Wu Z, Sagare A, Davis J, Du Yan S, Hamm K, et al. LRP/amyloid beta-peptide interaction mediates differential brain efflux of Abeta isoforms. Neuron. 2004:43.333-44.

33. Deane R, Bell RD, Sagare A, Zlokovic BV. Clearance of amyloid-beta peptide across the blood-brain barrier: implication for therapies in Alzheimer's disease. CNS Neurol Disord Drug Targets. 2009;8(1):16-30. https://doi.org/1 $0.2174 / 187152709787601867$

34. Chaudhuri A, Yang B, Gendelman HE, Persidsky Y, Kanmogne GD. STAT1 signaling modulates HIV-1-induced inflammatory responses and leukocyte transmigration across the blood-brain barrier. Blood. 2008;111:2062-72. 
35. Nair A, Jacob S. A simple practice guide for dose conversion between animals and human. J Basic Clin Pharm. 2016;7(2):27-31. https://doi.org/1 0.4103/0976-0105.177703.

36. Shin J-W, Seol I-C, Son C-G. Interpretation of animal dose and human equivalent dose for drug development. J Korean Orient Med. 2010;31:1-7.

37. Woollard SM, Li H, Singh S, Yu F, Kanmogne GD. HIV-1 induces cytoskeletal alterations and Rac1 activation during monocyte-blood-brain barrier interactions: modulatory role of CCR5. Retrovirology. 2014;11:20

38. Lan X, Xu J, Kiyota T, Peng H, Zheng JC, Ikezu T. HIV-1 reduces Abetadegrading enzymatic activities in primary human mononuclear phagocytes. J Immunol. 2011;186(12):6925-32. https://doi.org/10.4049/jimmunol.1100211.

39. Bhargavan B, Kanmogne GD. Differential mechanisms of inflammation and endothelial dysfunction by HIV-1 subtype-B and recombinant CRF02_AG tat proteins on human brain microvascular endothelial cells: implications for viral Neuropathogenesis. Mol Neurobiol. 2018;55:1352-63.

40. Chaudhuri A, Duan F, Morsey B, Persidsky Y, Kanmogne GD. HIV-1 activates proinflammatory and interferon-inducible genes in human brain microvascular endothelial cells: putative mechanisms of blood-brain barrie dysfunction. J Cereb Blood Flow Metab. 2008;28:697-711.

41. Deane R, Singh I, Sagare AP, Bell RD, Ross NT, LaRue B, et al. A multimodal RAGE-specific inhibitor reduces amyloid beta-mediated brain disorder in a mouse model of Alzheimer disease. J Clin Invest. 2012;122:1377-92.

42. Huang J, Gautam N, Bathena SP, Roy U, McMillan J, Gendelman HE, et al. UPLC-MS/MS quantification of nanoformulated ritonavir, indinavir, atazanavir, and efavirenz in mouse serum and tissues. J Chromatogr B Analyt Technol Biomed Life Sci. 2011;879:2332-8.

43. Bhargavan B, Woollard SM, Kanmogne GD. Toll-like receptor-3 mediates HIV1 transactivation via NFkappaB and JNK pathways and histone acetylation, but prolonged activation suppresses tat and HIV-1 replication. Cell Signal. 2016;28:7-22.

44. Deeks SG, Overbaugh J, Phillips A, Buchbinder S. HIV infection. Nat Rev Dis Primers. 2015;1:15035.

45. Cao W, Mehraj V, Kaufmann DE, Li T, Routy JP. Elevation and persistence of CD8 T-cells in HIV infection: the Achilles heel in the ART era. J Int AIDS Soc. 2016;19:20697

46. Fiala M, Cribbs DH, Rosenthal M, Bernard G. Phagocytosis of amyloid-beta and inflammation: two faces of innate immunity in Alzheimer's disease. J Alzheimers Dis. 2007;11(4):457-63. https://doi.org/10.3233/JAD-2007-11406.

47. Fiala M, Lin J, Ringman J, Kermani-Arab V, Tsao G, Patel A, et al. Ineffective phagocytosis of amyloid-beta by macrophages of Alzheimer's disease patients. J Alzheimers Dis. 2005;7(3):221-32; discussion 255-262. https://doi. org/10.3233/JAD-2005-7304.

48. Ries M, Sastre M. Mechanisms of Abeta clearance and degradation by glial cells. Front Aging Neurosci. 2016;8:160.

49. Zuroff L, Daley D, Black KL, Koronyo-Hamaoui M. Clearance of cerebral Abeta in Alzheimer's disease: reassessing the role of microglia and monocytes. Cell Mol Life Sci. 2017;74:2167-201.

50. Honeycutt JB, Sheridan PA, Matsushima GK, Garcia JV. Humanized mouse models for HIV-1 infection of the CNS. J Neuro-Oncol. 2015:21:301-9.

51. Roy U, McMillan J, Alnouti Y, Gautum N, Smith N, Balkundi S, et al. Pharmacodynamic and antiretroviral activities of combination nanoformulated antiretrovirals in HIV-1-infected human peripheral blood lymphocyte-reconstituted mice. J Infect Dis. 2012;206:1577-88.

52. Bhargavan B, Kanmogne GD. Epigenetics, N-myrystoyltransferase-1 and casein kinase-2-alpha modulates the increased replication of HIV-1 CRF02 AG, compared to subtype-B viruses. Sci Rep. 2019;9:10689.

53. Kim KC, Choi B-S, Kim K-C, Park KH, Lee HJ, Cho YK, et al. A simple mouse model for the study of human immunodeficiency virus. AIDS Res Hum Retrovir. 2016;32:194-202.

54. Li H, Singh S, Potula R, Persidsky Y, Kanmogne GD. Dysregulation of claudin5 in HIV-induced interstitial pneumonitis and lung vascular injury. Protective role of peroxisome proliferator-activated receptor-gamma. Am J Respir Crit Care Med. 2014;190:85-97.

55. Jin H, Sun Y, Li D, Lin M-H, Lor M, Rustanti L, et al. Strong In Vivo Inhibition of HIV-1 Replication by Nullbasic, a Tat Mutant. mBio. 2019;10:e01769-19.

56. Mukherjee R, Plesa G, Sherrill-Mix S, Richardson MW, Riley JL, Bushman FD. HIV sequence variation associated with env antisense adoptive T-cell therapy in the hNSG mouse model. Mol Ther J Am Soc Gene Ther. 2010;18:803-11.

57. Ferrer I, Hernandez I, Puig B, Rey MJ, Ezquerra M, Tolosa E, et al. Ubiquitinnegative mini-pick-like bodies in the dentate gyrus in p301l tauopathy. J Alzheimers Dis. 2003;5:445-54.
58. Rudrabhatla P, Jaffe H, Pant HC. Direct evidence of phosphorylated neuronal intermediate filament proteins in neurofibrillary tangles (NFTs): phosphoproteomics of Alzheimer's NFTs. FASEB J Off Publ Fed Am Soc Exp Biol. 2011:25:3896-905.

59. Ferrer I, Hernandez I, Boada M, Llorente A, Rey MJ, Cardozo A, et al. Primary progressive aphasia as the initial manifestation of corticobasal degeneration and unusual tauopathies. Acta Neuropathol. 2003;106:419-35.

60. Nagga K, Gottfries J, Blennow K, Marcusson J. Cerebrospinal fluid phosphotau, total tau and beta-amyloid (1-42) in the differentiation between Alzheimer's disease and vascular dementia. Dement Geriatr Cogn Disord. 2002:14:183-90.

61. Qiu L, Ng G, Tan EK, Liao P, Kandiah N, Zeng L. Chronic cerebral hypoperfusion enhances tau hyperphosphorylation and reduces autophagy in Alzheimer's disease mice. Sci Rep. 2016;6:23964.

62. Giunta B, Hou H, Zhu Y, Rrapo E, Tian J, Takashi M, et al. HIV-1 tat contributes to Alzheimer's disease-like pathology in PSAPP mice. Int J Clin Exp Pathol. 2009:2:433-43.

63. Aksenov MY, Aksenova MV, Mactutus CF, Booze RM. HIV-1 protein-mediated amyloidogenesis in rat hippocampal cell cultures. Neurosci Lett. 2010;475(3): 174-8. https://doi.org/10.1016/j.neulet.2010.03.073.

64. Chen X, Hui L, Geiger NH, Haughey NJ, Geiger JD. Endolysosome involvement in HIV-1 transactivator protein-induced neuronal amyloid beta production. Neurobiol Aging. 2013;34:2370-8.

65. Ortega M, Ances BM. Role of HIV in amyloid metabolism. J Neurolmmune Pharmacol. 2014;9:483-91.

66. Cho YE, Lee MH, Song BJ. Neuronal cell death and degeneration through increased Nitroxidative stress and tau phosphorylation in HIV-1 transgenic rats. PLoS ONE. 2017;12:e0169945.

67. Zeinolabediny Y, Caccuri F, Colombo L, Morelli F, Romeo M, Rossi A, et al. HIV-1 matrix protein p17 misfolding forms toxic amyloidogenic assemblies that induce neurocognitive disorders. Sci Rep. 2017;7:10313.

68. Chen J, Ren R, Yu F, Wang C, Zhang X, Li W, et al. A degraded fragment of HIV-1 Gp120 in rat hepatocytes forms fibrils and enhances HIV-1 infection. Biophys J. 2017:113:1425-39.

69. Wojtowicz WM, Farzan M, Joyal JL, Carter K, Babcock GJ, Israel DI, et al. Stimulation of enveloped virus infection by beta-amyloid fibrils. J Biol Chem 2002;277:35019-24.

70. Anderson AM, Croteau D, Ellis RJ, Rosario D, Potter M, Guillemin GJ, et al. HIV, prospective memory, and cerebrospinal fluid concentrations of quinolinic acid and phosphorylated tau. J Neuroimmunol. 2018;319:13-8.

71. Fulop T, Witkowski JM, Larbi A, Khalil A, Herbein G, Frost EH. Does HIV infection contribute to increased beta-amyloid synthesis and plaque formation leading to neurodegeneration and Alzheimer's disease. $J$ Neurovirol. 2019;25:634-47.

72. Nunan J, Small DH. Proteolytic processing of the amyloid-beta protein precursor of Alzheimer's disease. Essays Biochem. 2002;38:37-49.

73. Agostinho P, Pliassova A, Oliveira CR, Cunha RA. Localization and trafficking of amyloid-beta protein precursor and secretases: impact on Alzheimer's disease. J Alzheimers Dis. 2015:45:329-47.

74. Funamoto S, Tagami S, Okochi M, Morishima-Kawashima M. Successive cleavage of beta-amyloid precursor protein by gamma-secretase. Semin Cell Dev Biol. 2020;105:64-74.

75. Chu J, Li JG, Joshi YB, Giannopoulos PF, Hoffman NE, Madesh M, et al. Gamma secretase-activating protein is a substrate for caspase-3: implications for Alzheimer's disease. Biol Psychiatry. 2015;77:720-8.

76. Perez SE, Nadeem M, Malek-Ahmadi MH, He B, Mufson EJ. Frontal cortex and hippocampal gamma-secretase activating protein levels in prodromal Alzheimer disease. Neurodegener Dis. 2017;17:235-41.

77. Satoh J, Tabunoki H, Ishida T, Saito Y, Arima K. Immunohistochemical characterization of gamma-secretase activating protein expression in Alzheimer's disease brains. Neuropathol Appl Neurobiol. 2012;38:132-41.

78. Chu J, Wisniewski T, Pratico D. GATA1-mediated transcriptional regulation of the gamma-secretase activating protein increases Abeta formation in Down syndrome. Ann Neurol. 2016;79:138-43.

79. Chu J, Lauretti E, Craige CP, Pratico D. Pharmacological modulation of GSAP reduces amyloid-beta levels and tau phosphorylation in a mouse model of Alzheimer's disease with plaques and tangles. J Alzheimers Dis. 2014;41:729-37.

80. Hussain I, Fabregue J, Anderes L, Ousson S, Borlat F, Eligert V, et al. The role of gamma-secretase activating protein (GSAP) and imatinib in the regulation of gamma-secretase activity and amyloid-beta generation. J Biol Chem. 2013;288:2521-31. 
81. Wong E, Liao GP, Chang JC, Xu P, Li YM, Greengard P. GSAP modulates gamma-secretase specificity by inducing conformational change in PS1. Proc Natl Acad Sci U S A. 2019;116(13):6385-90. https://doi.org/10.1073/pna S. 1820160116

82. Teunissen CE, Chiu MJ, Yang CC, Yang SY, Scheltens P, Zetterberg H, et al. Plasma amyloid-beta (Abeta42) correlates with cerebrospinal fluid Abeta42 in Alzheimer's disease. J Alzheimers Dis. 2018;62:1857-63.

83. Seppala TT, Herukka SK, Hanninen T, Tervo S, Hallikainen M, Soininen H, et al. Plasma Abeta42 and Abeta40 as markers of cognitive change in follow-up: a prospective, longitudinal, population-based cohort study. J Neurol Neurosurg Psychiatry. 2010;81:1123-7.

84. Risacher SL, Fandos N, Romero J, Sherriff I, Pesini P, Saykin AJ, et al. Plasma amyloid beta levels are associated with cerebral amyloid and tau deposition. Alzheimers Dement (Amst). 2019;11:510-9.

85. Hilal S, Wolters FJ, Verbeek MM, Vanderstichele H, Ikram MK, Stoops E, et al. Plasma amyloid-beta levels, cerebral atrophy and risk of dementia: a population-based study. Alzheimers Res Ther. 2018;10:63.

86. Chouraki V, Beiser A, Younkin L, Preis SR, Weinstein G, Hansson O, et al. Plasma amyloid-beta and risk of Alzheimer's disease in the Framingham heart study. Alzheimers Dement. 2015;11(e241):249-57.

87. Graff-Radford NR, Crook JE, Lucas J, Boeve BF, Knopman DS, Ivnik RJ, et al. Association of low plasma Abeta42/Abeta40 ratios with increased imminent risk for mild cognitive impairment and Alzheimer disease. Arch Neurol. 2007:64:354-62

88. Wang J, Qiao F, Shang S, Li P, Chen C, Dang L, et al. Elevation of plasma amyloid-beta level is more significant in early stage of cognitive impairment: a population-based cross-sectional study. J Alzheimers Dis. 2018;64:61-9.

89. Cosentino SA, Stern Y, Sokolov E, Scarmeas N, Manly JJ, Tang MX, et al. Plasma ss-amyloid and cognitive decline. Arch Neurol. 2010;67:1485-90.

90. Schupf N, Tang MX, Fukuyama H, Manly J, Andrews H, Mehta P, et al. Peripheral Abeta subspecies as risk biomarkers of Alzheimer's disease. Proc Natl Acad Sci U S A. 2008;105:14052-7.

91. Assini A, Cammarata S, Vitali A, Colucci M, Giliberto L, Borghi R, et al. Plasma levels of amyloid beta-protein 42 are increased in women with mild cognitive impairment. Neurology. 2004;63:828-31.

92. Luis CA, Abdullah L, Paris D, Quadros A, Mullan M, Mouzon B, et al. Serum beta-amyloid correlates with neuropsychological impairment. Neuropsychol Dev Cogn B Aging Neuropsychol Cogn. 2009;16:203-18.

93. Wang MJ, Yi S, Han JY, Park SY, Jang JW, Chun IK, et al. Oligomeric forms of amyloid-beta protein in plasma as a potential blood-based biomarker for Alzheimer's disease. Alzheimers Res Ther. 2017;9:98.

94. Burnham SC, Fandos N, Fowler C, Perez-Grijalba V, Dore V, Doecke JD, et al. Longitudinal evaluation of the natural history of amyloid-beta in plasma and brain. Brain Commun. 2020;2:fcaa041.

95. Fan LY, Tzen KY, Chen YF, Chen TF, Lai YM, Yen RF, et al. The relation between brain amyloid deposition, cortical atrophy, and plasma biomarkers in amnesic mild cognitive impairment and Alzheimer's disease. Front Aging Neurosci. 2018;10:175

96. Nabers A, Perna L, Lange J, Mons U, Schartner J, Guldenhaupt J, et al. Amyloid blood biomarker detects Alzheimer's disease. EMBO Mol Med. 2018;10:e8763

97. Perez-Grijalba V, Romero J, Pesini P, Sarasa L, Monleon I, San-Jose I, et al Plasma Abeta42/40 ratio detects early stages of Alzheimer's disease and correlates with CSF and neuroimaging biomarkers in the AB255 study. J Prev Alzheimers Dis. 2019;6:34-41.

98. Park JC, Han SH, Yi D, Byun MS, Lee JH, Jang S, et al. Plasma tau/amyloidbeta1-42 ratio predicts brain tau deposition and neurodegeneration in Alzheimer's disease. Brain. 2019;142(3):771-86. https://doi.org/10.1093/bra in/awy347.

99. Feinkohl I, Schipke CG, Kruppa J, Menne F, Winterer G, Pischon T, et al. Plasma amyloid concentration in Alzheimer's disease: performance of a high-throughput amyloid assay in distinguishing Alzheimer's disease cases from controls. J Alzheimers Dis. 2020;74:1285-94.

100. Seino $Y$, Nakamura T, Kawarabayashi T, Hirohata M, Narita S, Wakasaya Y, et al. Cerebrospinal fluid and plasma biomarkers in neurodegenerative diseases. J Alzheimers Dis. 2019;68:395-404.

101. Hansson $O$, Zetterberg $H$, Vanmechelen $E$, Vanderstichele $H$, Andreasson $U$, Londos E, et al. Evaluation of plasma Abeta (40) and Abeta (42) as predictors of conversion to Alzheimer's disease in patients with mild cognitive impairment. Neurobiol Aging. 2010;31:357-67.
102. Lovheim $H$, Elgh $F$, Johansson A, Zetterberg $H$, Blennow $K$, Hallmans $G$, et al. Plasma concentrations of free amyloid beta cannot predict the development of Alzheimer's disease. Alzheimers Dement. 2017;13:778-82.

103. Lewczuk P, Ermann N, Andreasson U, Schultheis C, Podhorna J, Spitzer P, et al. Plasma neurofilament light as a potential biomarker of neurodegeneration in Alzheimer's disease. Alzheimers Res Ther. 2018;10(1): 71. https://doi.org/10.1186/s13195-018-0404-9.

104. Shoda C, Kitagawa Y, Shimada H, Yuzawa M, Tateno A, Okubo Y. Relationship of area of soft Drusen in retina with cerebral amyloid-beta accumulation and blood amyloid-beta level in the elderly. J Alzheimers Dis. 2018;62:239-45

105. de Almeida SM, Ribeiro CE, Rotta I, Letendre S, Potter M, Tang B, et al. Group HIVNRC: blood amyloid-beta protein isoforms are affected by HIV-1 in a subtype-dependent pattern. J Neuro-Oncol. 2020;26:3-13.

106. Mothapo KM, Stelma F, Janssen M, Kessels R, Miners S, Verbeek MM, et al. Amyloid beta-42 (Abeta-42), neprilysin and cytokine levels. A pilot study in patients with HIV related cognitive impairments. J Neuroimmunol. 2015;282:73-9.

107. Kuo YM, Emmerling MR, Lampert HC, Hempelman SR, Kokjohn TA, Woods AS, et al. High levels of circulating Abeta42 are sequestered by plasma proteins in Alzheimer's disease. Biochem Biophys Res Commun. 1999;257: 787-91.

108. Mehta PD, Pirttila T, Patrick BA, Barshatzky M, Mehta SP. Amyloid beta protein 1-40 and 1-42 levels in matched cerebrospinal fluid and plasma from patients with Alzheimer disease. Neurosci Lett. 2001;304:102-6.

109. Vanderstichele H, Van Kerschaver E, Hesse C, Davidsson P, Buyse MA, Andreasen N, et al. Standardization of measurement of beta-amyloid (1-42) in cerebrospinal fluid and plasma. Amyloid. 2000;7:245-58.

110. Freeman SH, Raju S, Hyman BT, Frosch MP, Irizarry MC. Plasma Abeta levels do not reflect brain Abeta levels. J Neuropathol Exp Neurol. 2007;66:264-71.

111. Kim J, Yoon JH, Kim YS. HIV-1 tat interacts with and regulates the localization and processing of amyloid precursor protein. PLOS ONE. 2013;8: e77972.

112. Gannon PJ, Akay-Espinoza C, Yee AC, Briand LA, Erickson MA, Gelman BB, et al. HIV protease inhibitors Alter amyloid precursor protein processing via beta-site amyloid precursor protein cleaving Enzyme-1 translational upregulation. Am J Pathol. 2017:187:91-109.

113. Lan X, Kiyota T, Hanamsagar R, Huang Y, Andrews S, Peng H, et al. The effect of HIV protease inhibitors on amyloid-beta peptide degradation and synthesis in human cells and Alzheimer's disease animal model. J Neurolmmune Pharmacol. 2012;7:412-23.

114. Lederman MM, Penn-Nicholson A, Cho M, Mosier D. Biology of CCR5 and its role in HIV infection and treatment. JAMA. 2006;296:815-26.

115. Brelot A, Chakrabarti LA. CCR5 revisited: how mechanisms of HIV entry govern AIDS pathogenesis. J Mol Biol. 2018;430:2557-89.

116. Maung R, Hoefer MM, Sanchez AB, Sejbuk NE, Medders KE, Desai MK, et al. CCR5 knockout prevents neuronal injury and behavioral impairment induced in a transgenic mouse model by a CXCR4-using HIV-1 glycoprotein 120. J Immunol. 2014;193:1895-910.

117. Martin-Blondel G, Brassat D, Bauer J, Lassmann H, Liblau RS. CCR5 blockade for neuroinflammatory diseases--beyond control of HIV. Nat Rev Neurol. 2016:12:95-105.

118. Gonek M, McLane VD, Stevens DL, Lippold K, Akbarali HI, Knapp PE, et al. CCR5 mediates HIV-1 tat-induced neuroinflammation and influences morphine tolerance, dependence, and reward. Brain Behav Immun. 2018;69: 124-38. https://doi.org/10.1016/j.bbi.2017.11.006

119. Xia M, Qin S, Wu L, Mackay CR, Hyman BT. Immunohistochemical study of the $\beta$-chemokine receptors CCR3 and CCR5 and their ligands in Normal and Alzheimer's disease brains. Am J Pathol. 1998;153:31-7.

120. Giri RK, Rajagopal V, Shahi S, Zlokovic BV, Kalra VK. Mechanism of amyloid peptide induced CCR5 expression in monocytes and its inhibition by siRNA for Egr-1. Am J Physiol Cell Physiol. 2005;289:C264-76.

121. Li M, Shang DS, Zhao WD, Tian L, Li B, Fang WG, et al. Amyloid beta interaction with receptor for advanced glycation end products up-regulates brain endothelial CCR5 expression and promotes T cells crossing the bloodbrain barrier. J Immunol. 2009;182:5778-88.

122. Mondal S, Rangasamy SB, Roy A, Dasarathy S, Kordower JH, Pahan K. Lowdose Maraviroc, an antiretroviral drug, attenuates the infiltration of T cells into the central nervous system and protects the Nigrostriatum in Hemiparkinsonian monkeys. J Immunol. 2019.

123. Kelly KM, Beck SE, Metcalf Pate KA, Queen SE, Dorsey JL, Adams RJ, et al. Neuroprotective maraviroc monotherapy in simian immunodeficiency virus- 
infected macaques: reduced replicating and latent SIV in the brain. AIDS 2013;27:F21-8

124. Letendre S. Central nervous system complications in HIV disease: HIVassociated neurocognitive disorder. Top Antivir Med. 2011;19:137-42.

125. Yilmaz A, Watson V, Else L, Gisslen M. Cerebrospinal fluid maraviroc concentrations in HIV-1 infected patients. AIDS. 2009;23:2537-40.

126. Tiraboschi JM, Niubo J, Curto J, Podzamczer D. Maraviroc concentrations in cerebrospinal fluid in HIV-infected patients. J Acquir Immune Defic Syndr. 2010;55:606-9

127. Croteau D, Best BM, Letendre S, Rossi SS, Ellis RJ, Clifford DB, et al. Lower than expected maraviroc concentrations in cerebrospinal fluid exceed the wild-type CC chemokine receptor 5-tropic HIV-1 50\% inhibitory concentration. AIDS. 2012;26:890-3.

128. Lue LF, Walker DG, Brachova L, Beach TG, Rogers J, Schmidt AM, et al. Involvement of microglial receptor for advanced glycation endproducts (RAGE) in Alzheimer's disease: identification of a cellular activation mechanism. Exp Neurol. 2001;171:29-45.

129. Yan SD, Chen X, Fu J, Chen M, Zhu H, Roher A, et al. RAGE and amyloidbeta peptide neurotoxicity in Alzheimer's disease. Nature. 1996;382:685-91.

130. Yan SS, Chen D, Yan S, Guo L, Du H, Chen JX: RAGE is a key cellular target for Abeta-induced perturbation in Alzheimer's disease. Front Biosci (Schol Ed) 2012, 4:240-250

131. Arancio O, Zhang HP, Chen X, Lin C, Trinchese F, Puzzo D, et al. RAGE potentiates Abeta-induced perturbation of neuronal function in transgenic mice. EMBO J. 2004:23:4096-105.

132. Ndhlovu LC, Umaki T, Chew GM, Chow DC, Agsalda M, Kallianpur KJ, et al. Treatment intensification with maraviroc (CCR5 antagonist) leads to declines in CD16-expressing monocytes in CART-suppressed chronic HIV-infected subjects and is associated with improvements in neurocognitive test performance: implications for HIV-associated neurocognitive disease (HAND). J Neuro-Oncol. 2014;20:571-82.

133. Gates TM, Cysique LA, Siefried KJ, Chaganti J, Moffat KJ, Brew BJ. Maravirocintensified combined antiretroviral therapy improves cognition in virally suppressed HIV-associated neurocognitive disorder. AIDS. 2016;30:591-600.

134. Mora-Peris B, Bouliotis G, Ranjababu K, Clarke A, Post FA, Nelson M, et al. Changes in cerebral function parameters with maraviroc-intensified antiretroviral therapy in treatment naive HIV-positive individuals. AIDS. 2018; 32:1007-15.

135. Tiraboschi JM, Munoz-Moreno JA, Puertas MC, Alonso-Villaverde C, Prats A,

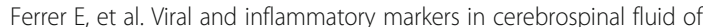
patients with HIV-1-associated neurocognitive impairment during antiretroviral treatment switch. HIV Med. 2015;16:388-92.

136. Valcour VG, Spudich SS, Sailasuta N, Phanuphak N, Lerdlum S, Fletcher JL, et al. Neurological Response to cART vs. CART plus Integrase Inhibitor and CCR5 Antagonist Initiated during Acute HIV. PLOS ONE. 2015;10:e0142600.

137. Barber TJ, Imaz A, Boffito M, Niubo J, Pozniak A, Fortuny R, et al. CSF inflammatory markers and neurocognitive function after addition of maraviroc to monotherapy darunavir/ritonavir in stable HIV patients: the CINAMMON study. J Neuro-Oncol. 2018;24(1):98-105. https://doi.org/10.1 007/s13365-017-0600-6.

138. Kovalevich J, Langford D. Neuronal toxicity in HIV CNS disease. Future Virol. 2012;7:687-98

139. Ru W, Tang SJ. HIV-associated synaptic degeneration. Mol Brain. 2017;10:40.

140. Vickers JC, Dickson TC, Adlard PA, Saunders HL, King CE, McCormack G. The cause of neuronal degeneration in Alzheimer's disease. Prog Neurobiol. 2000;60:139-65.

141. Wenk GL. Neuropathologic changes in Alzheimer's disease. J Clin Psychiatry. 2003;64(Suppl 9):7-10.

142. Perl DP. Neuropathology of Alzheimer's disease. Mt Sinai J Med. 2010;77:32-42.

143. Kim S, Hahn YK, Podhaizer EM, McLane VD, Zou S, Hauser KF, et al. A central role for glial CCR5 in directing the neuropathological interactions of HIV-1 tat and opiates. J Neuroinflammation. 2018;15:285.

144. Garvey L, Nelson M, Latch N, Erlwein OW, Allsop JM, Mitchell A, et al. CNS effects of a CCR5 inhibitor in HIV-infected subjects: a pharmacokinetic and cerebral metabolite study. J Antimicrob Chemother. 2012;67:206-12.

145. Joy MT, Ben Assayag E, Shabashov-Stone D, Liraz-Zaltsman S, Mazzitelli J, Arenas M, et al. CCR5 Is a Therapeutic Target for Recovery after Stroke and Traumatic Brain Injury. Cell. 2019;176(e1113):1143-57.

146. Abbott NJ, Patabendige AA, Dolman DE, Yusof SR, Begley DJ. Structure and function of the blood-brain barrier. Neurobiol Dis. 2010:37:13-25.
147. Obermeier B, Daneman R, Ransohoff RM. Development, maintenance and disruption of the blood-brain barrier. Nat Med. 2013;19(12):1584-96. https:// doi.org/10.1038/nm.3407.

148. Morita K, Sasaki H, Furuse M, Tsukita S. Endothelial claudin: claudin-5/TMVCF constitutes tight junction strands in endothelial cells. J Cell Biol. 1999;147: 185-94.

149. Kniesel U, Wolburg H. Tight junctions of the blood-brain barrier. Cell Mol Neurobiol. 2000;20(1):57-76. https://doi.org/10.1023/A:1006995910836.

150. Bauer H, Stelzhammer W, Fuchs R, Weiger TM, Danninger C, Probst G, et al. Astrocytes and neurons express the tight junction-specific protein occludin in vitro. Exp Cell Res. 1999;250:434-8.

151. Wachtel M, Bolliger MF, Ishihara H, Frei K, Bluethmann H, Gloor SM. Downregulation of occludin expression in astrocytes by tumour necrosis factor (TNF) is mediated via TNF type-1 receptor and nuclear factor-kappaB activation. J Neurochem. 2001:78:155-62.

152. Shimizu F, Sano Y, Maeda T, Abe MA, Nakayama H, Takahashi R, et al. Peripheral nerve pericytes originating from the blood-nerve barrier expresses tight junctional molecules and transporters as barrier-forming cells. J Cell Physiol. 2008;217:388-99.

153. Howarth AG, Hughes MR, Stevenson BR. Detection of the tight junctionassociated protein ZO-1 in astrocytes and other nonepithelial cell types. Am J Phys. 1992;262:C461-9.

154. Duffy HS, John GR, Lee SC, Brosnan CF, Spray DC. Reciprocal regulation of the junctional proteins claudin-1 and connexin 43 by interleukin-1 beta in primary human fetal astrocytes. J Neurosci. 2000;20:RC114.

155. Li X, lonescu AV, Lynn BD, Lu S, Kamasawa N, Morita M, et al. Connexin47, connexin29 and connexin32 co-expression in oligodendrocytes and Cx47 association with zonula occludens-1 (ZO-1) in mouse brain. Neuroscience. 2004;126:611-30.

156. Nitta T, Hata M, Gotoh S, Seo Y, Sasaki H, Hashimoto N, et al. Size-selective loosening of the blood-brain barrier in claudin-5-deficient mice. J Cell Biol. 2003;161:653-60.

157. Bauer HC, Krizbai IA, Bauer H, Traweger A. "you shall not pass"-tight junctions of the blood brain barrier. Front Neurosci. 2014;8:392.

158. Zihni C, Mills C, Matter K, Balda MS. Tight junctions: from simple barriers to multifunctional molecular gates. Nat Rev Mol Cell Biol. 2016;17:564-80.

159. Sweeney MD, Sagare AP, Zlokovic BV. Blood-brain barrier breakdown in Alzheimer disease and other neurodegenerative disorders. Nat Rev Neurol. 2018;14:133-50.

160. Banks WA, Ercal N, Price TO. The blood-brain barrier in neuroAIDS. Curr HIV Res. 2006;:259-66.

161. Yamazaki Y, Kanekiyo T. Blood-brain barrier dysfunction and the pathogenesis of Alzheimer's disease. Int J Mol Sci. 2017;18.

162. Cai Z, Qiao PF, Wan CQ, Cai M, Zhou NK, Li Q. Role of blood-brain barrier in Alzheimer's disease. J Alzheimers Dis. 2018;63(4):1223-34. https://doi.org/1 0.3233/JAD-180098.

163. Gosselet F, Saint-Pol J, Candela P, Fenart L. Amyloid-beta peptides, Alzheimer's disease and the blood-brain barrier. Curr Alzheimer Res. 2013;10: 1015-33.

164. Canet G, Dias C, Gabelle A, Simonin Y, Gosselet F, Marchi N, et al. HIV Neuroinfection and Alzheimer's disease: similarities and potential links? Front Cell Neurosci. 2018;12:307.

165. Man S-M, Ma Y-R, Shang D-S, Zhao W-D, Li B, Guo D-W, et al. Peripheral T cells overexpress MIP-1a to enhance its transendothelial migration in Alzheimer's disease. Neurobiol Aging. 2007;28:485-96.

166. Yang B, Singh S, Bressani R, Kanmogne GD. Cross-talk between STAT1 and PI3K JAKT signaling in HIV-1-induced blood-brain barrier dysfunction: role of CCR5 and implications for viral neuropathogenesis. J Neurosci Res. 2010;88: 3090-101.

\section{Publisher's Note}

Springer Nature remains neutral with regard to jurisdictional claims in published maps and institutional affiliations. 